\title{
III. $\mathrm{X}$ 線写真撮影用具について (Positioning の 補 助 用 具)
}

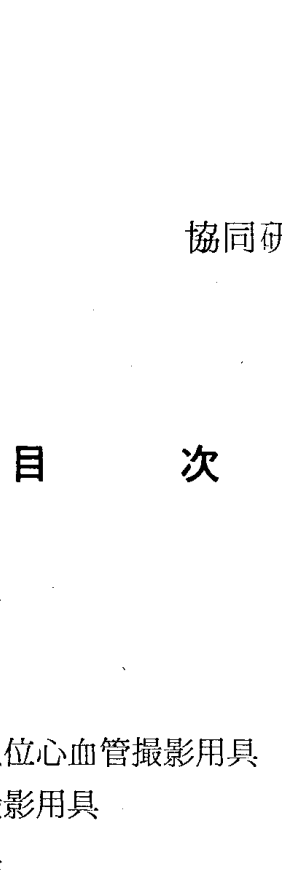

岡崎

長

北海道大学

藤木 幹 雄

I . 緒 言

II. 胸部撮影用具
1. 成人用
2. 小児用

III. 小览用立, 臥位心血管撮影用具

IV. 簡易脳血管撮影用具

V. 脊椎撮影用具

1. 斜位撮影用

2. 立位側面位屈伸撮影用

VI. 骨盤および股関節撮影用具

VII. 結論および謝辞

\section{緒言}

X線写真を撮影する場合は positioning がきわめて重 要であるというととは,だれしむ周知のととであります. しかし従来ともすれば，むっとも重要な positioning が われわれ技師の経験や，感にたよる，いわゆる名人芸的 なやり方で行なわれたととす否定できない事実でありま す. 私に positioning の補助用具という演題を与えれた 最大の理由はX線技師のだれしもが，何時，いかなる場 合にも，補助用具を使用するととにより，正しい，そし て再現性のある客観性を持った positioning を行ない得

(1) 正しい positioning が得られること

(2) 再 現 性

（3）被写体の動摇によるボケの防止

(4) 被写体の疲労の軽減

(5) 術者の使用上の簡便

(6) 被爆線量の減少

第1図Positioning 用補助用具の必要条件
るようにするためにあると思います。

したがって positioning の補助用具は第 1 図のような 条件を満すすのでなければならない。

すなわち患者の肉体的および精神的負担を軽减せしぬ 他方では，幾何学的な条件を満足せしめ，かつ再現性の あることが必要である．以上の観点からして, 私は胸部， 脊椎, 股関節，小児等の positioning の補助用具を検討 したので報告致します。.

\section{II. 胸 部撮影用具}

\section{（1）成人用}

緒 言

成人用の胸部撮影に当っては, 補助用具を必要とする のは，乳幼児であることは論を待たないととろでありあ りますが，大人の場合に補助用具が有ってもなくてもい いのか，いささか反省する必要があります。昔からわれ われX線技師の間では，X線写真は胸部に始まり胸部に 終わるという伝があるように胸部写真は簡単なようで反 面, 非常に難しいとも考えられます。

患者をリーダーの前に立たせれば，何時でむ正しい正

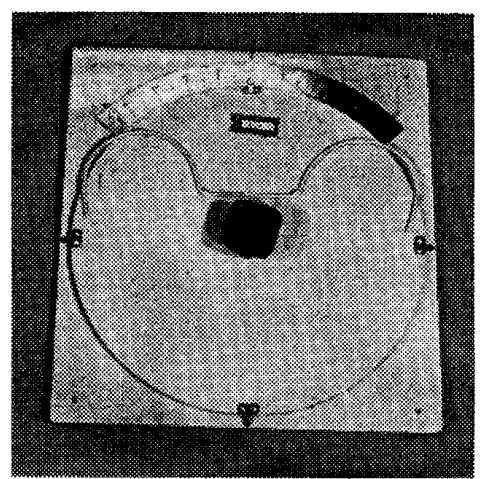

第 2 図

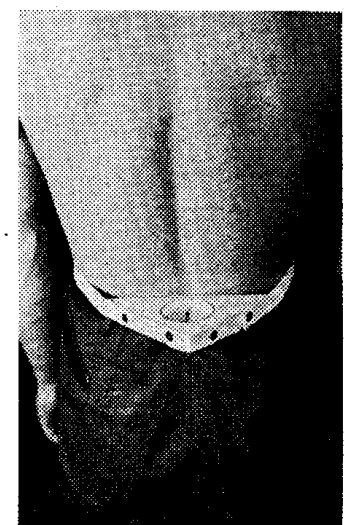

第 3 図 
面像が撮られるように思いますが，事実は決してそうで はありません。

試作検討

以上の钼点より第 2，3図のような胸部撮影回転台の 足の位置の上に泟しく患者を立せます，乙の回転台には 回転角度を示す目盛があるので角度は容易に知ることが できます、その際胸部のネジれを少しでも除去するため に磁気角度計で回転角度の補Eならびに測定を行なうも

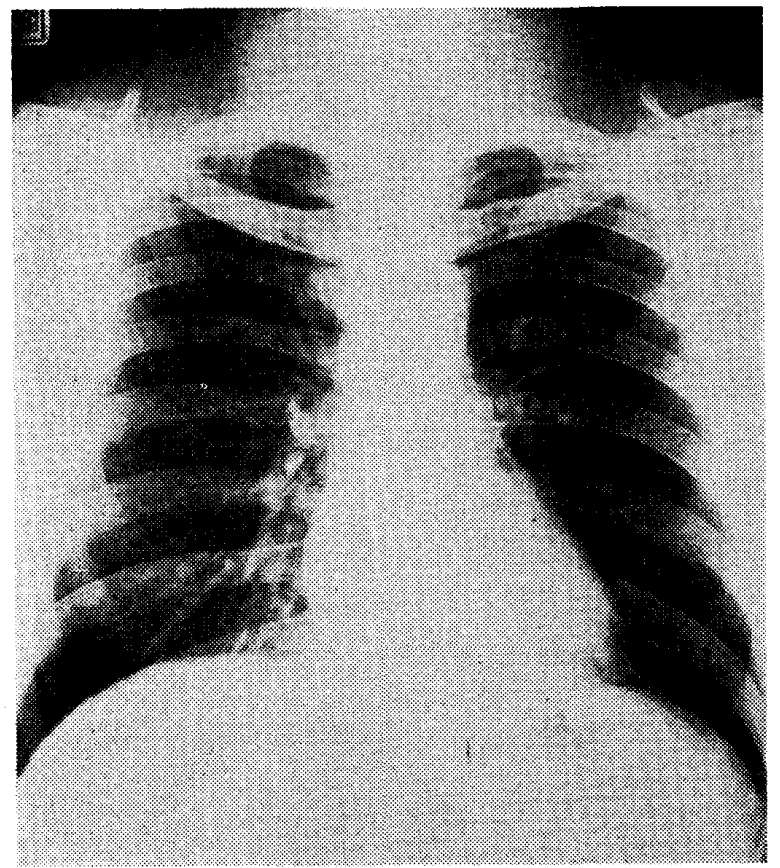

第 4 図

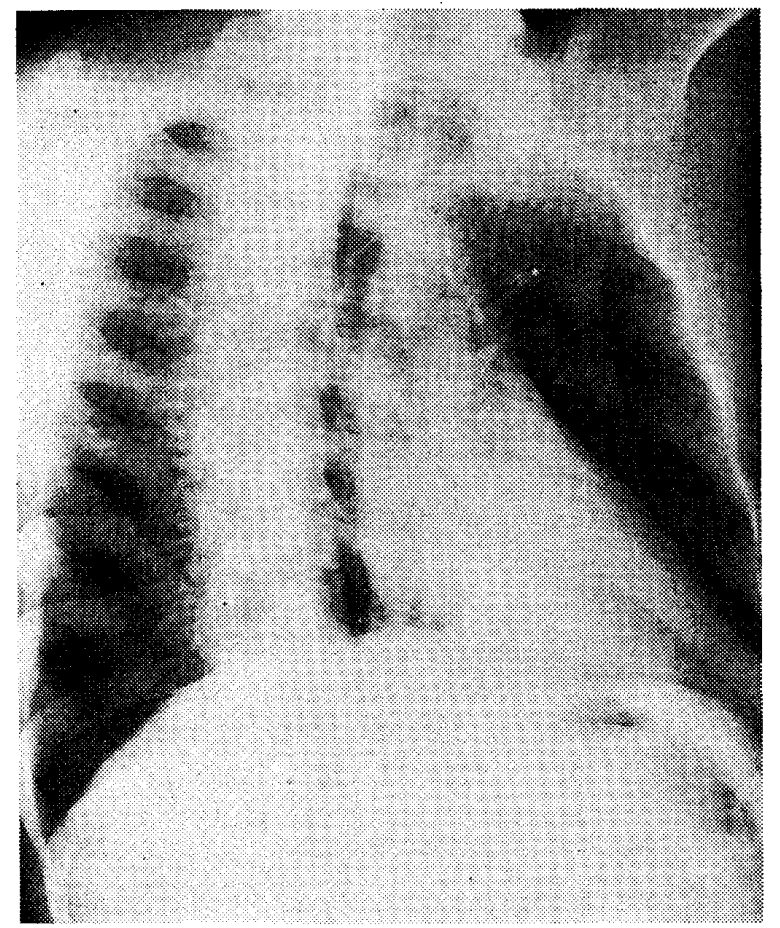

第 5 図
のであります。

簡単なようですが，とれだけでも positioning が正確 に再現性を持って行なわれるようになりました。

実際に撮影した写真が第 4，5図の通りであります。

\section{（2）小 児 用}

緒 言

小児は聞き分けがなく，良く動くので，昔からいろい ろの補助用具が，考案されておりますが，その実物は第 6，7図に示すように座居型，懸垂型等は広く用いられ ています。われわれは卧位撮影用補助用具を試作検討し た.

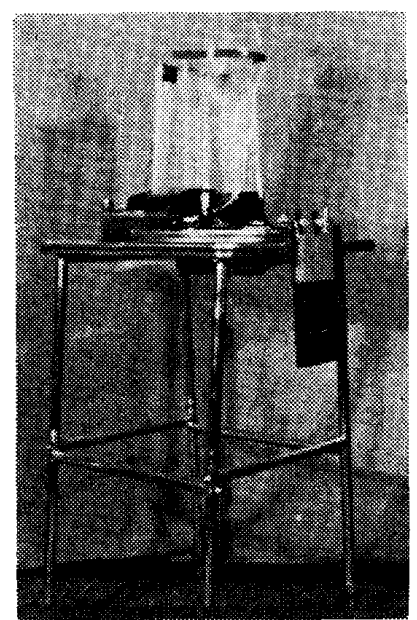

第 6 図

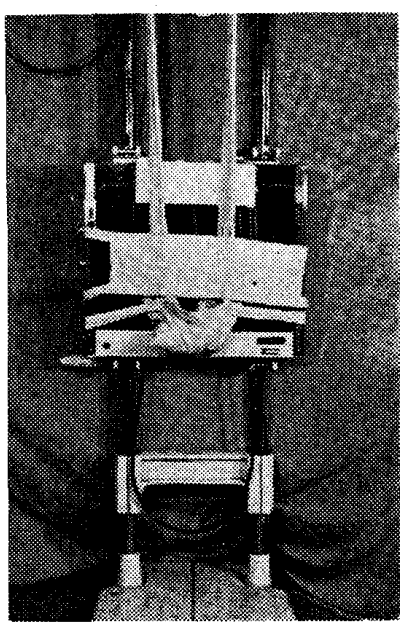

第 7 図
試作検討

用具試作に当たっては小児の体格を生後 2 カ月より 7 歳までの約30名を測定し各部位の最大, 最小および平均 值を出した，第 8 図にもとついてT字型の木製撮影台を 作り長軸方, 方向に幅 $55 \mathrm{~cm}$ の布をハンモック状に張り 張調節を可能にし台全体も移動可能にした．第 $9,10,11$ 図のような実際に使用しているものであり，きわめて簡 単な撮影台であり，また取り扱いが頗る容易であるにか かわらずハンモックのセンターに幼児を位置させること により正確な正面像が得られ，右，左端に位置させると とにより斜位像が得られる。

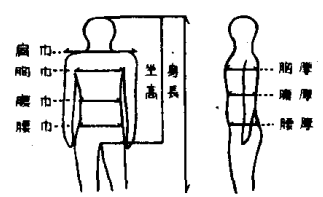

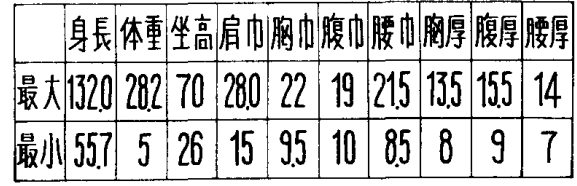

第 8 図 


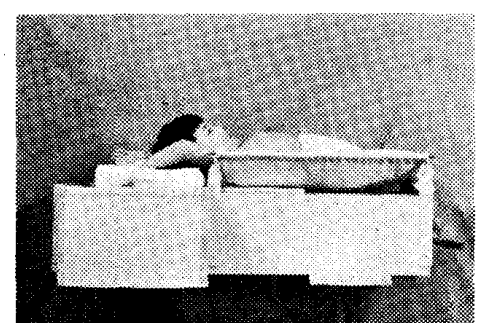

第 9 図

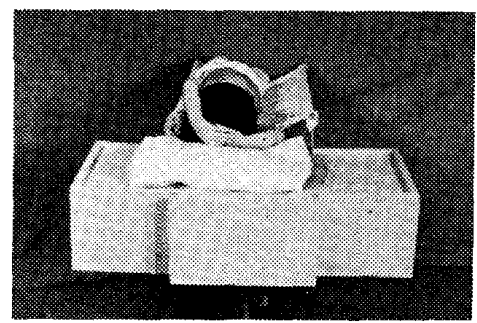

第 10 図

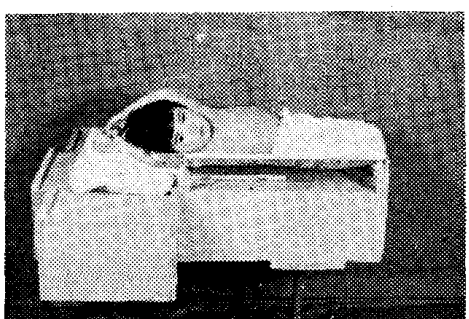

第 11 図

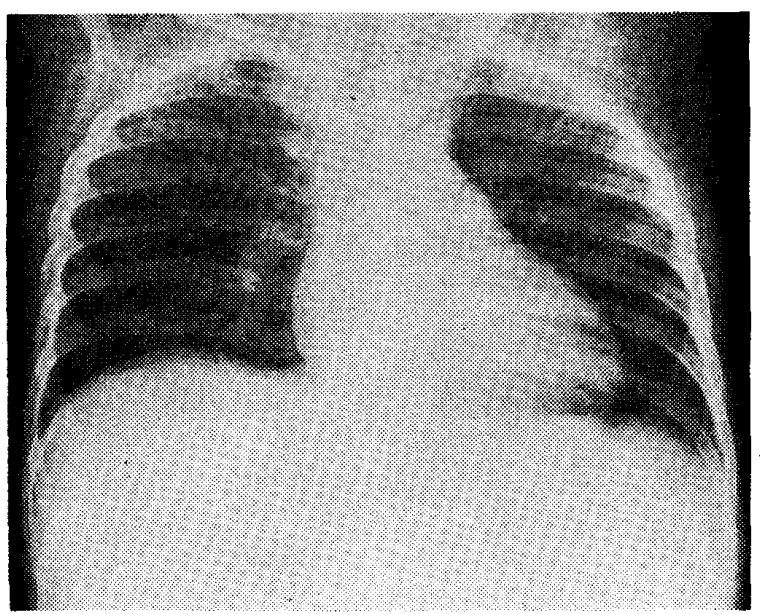

第 12 図

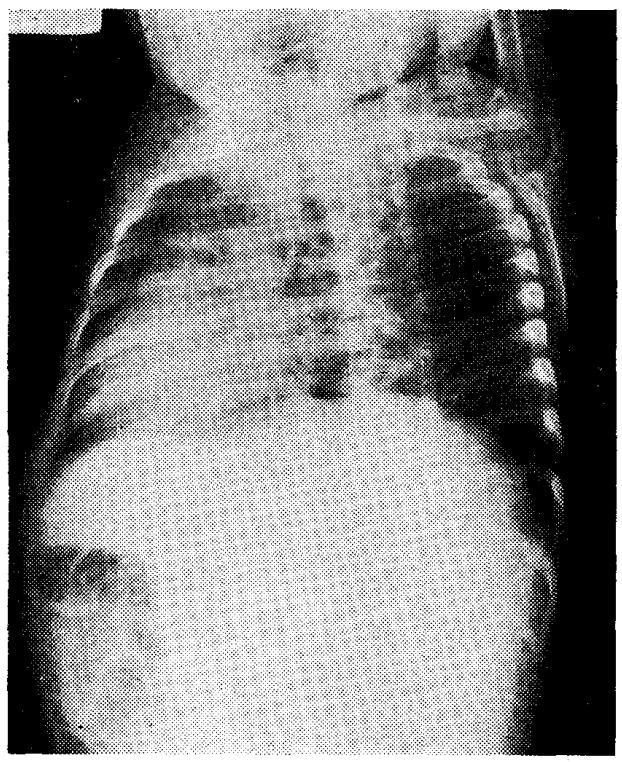

第 13 図

第12，13図は日常診断供される写真であります。奻 児はあたかもハンモックに横たわる気分で固い撮影台に 置かれる場合よりも恐扸感がなく，安静度在保つ度合の 多いという利点があります。

\section{III. 小児用立, 臥位心血管撮影用具}

緒 䓂

最近小児の心臓奖患の検査彰断は急激な進歩を見せて
いる．小児の心臓弁膜運動，心房あるいは心室間の短絡 の有無, 大血管の走行異常冠動脈壁の拡張, 移植人工弁 膜運動等の研究を行なうについて小児の体位および角度 の固定が必要にいたってきた。とのような診断上の要求 に添う体位の設定，再現性および確実な固定をでき得る 固定具を考案した。本用其は TV 透視装置に取り付けら れ $16 \mathrm{~mm}$ 高速度力メラ, 再確認用の V.T.R 心内理曲線 記録話，インヂェクタ一, ECG 等の各装置之組合わせ 彰断価值のあるものに央用化したので報告する。

武作検討

本用具の試作に当たっては第 8 四の寸法によりアクリ ル樹脂板の半ダ円形を作り頭部より腰部までの体側を鈜 んで固定する，第14，15図は取り付けた用具である.

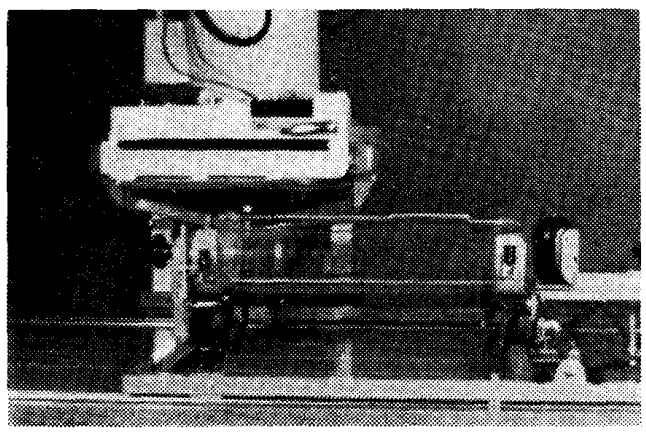

第 14 図

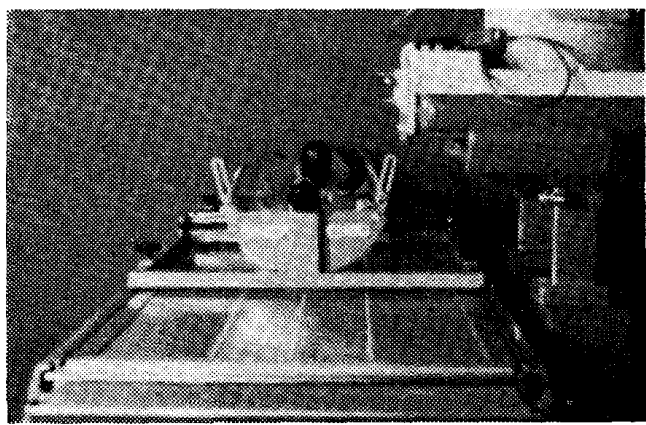

第 15 図

本用具の使用により患者の完全固定と仰臥位加ら側卧 位までのあらゆる体位の角度とさらに立位から卧位方向 の体位が可能にしてあります。第16図はその可動範囲を 
示すものであります。
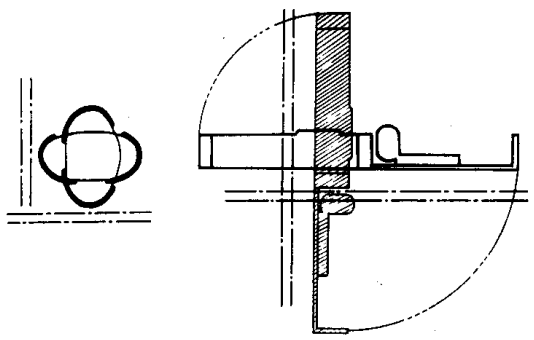

第16図 乳小児心臓血管撮影固定器の可動範囲 乳幼児の体格は第 8 図のように身長, 体重，屑幅等にかな り広範の開きがある ので，患者の体を固 定するアクリル樹脂 板を第17図のように 固定範囲を抁げ，幅

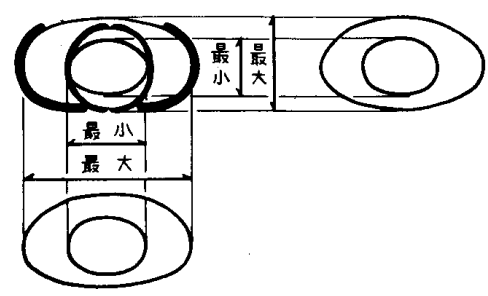

第17図 乳小监血管撮影用 固定器の固定範囲
$10 \mathrm{~cm} \sim 28 \mathrm{~cm}$ まで自由に変化せしめるようにした。 その 実物は第18，19图のようになる。

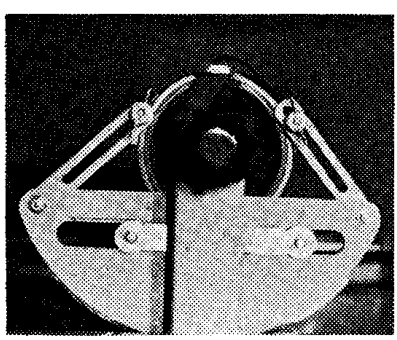

第 18 図

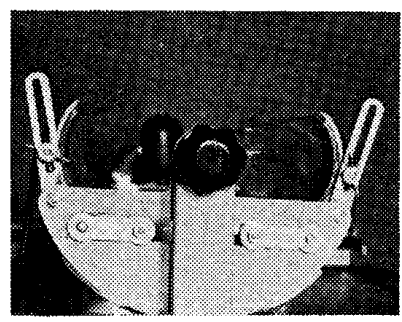

第 19 図
この樹脂板の長さを $60 \mathrm{~cm}$ とし立位の場合は患者の坐 高に志じて患者の体重を支いる鞍を上下するようにして ある，第20図はその機構図である，さら江固定部全体を 左右90度まで回転するようにして正面から側面まで可動 にして，画車にて完全固定を施してある，その写真は第 21，22，23図であり固定状態の爾車，スケーラー等であ る.また使用したアクリル樹脂板は強度および加工上厚 さ $6 \mathrm{~mm}$ を使用した．乙の樹脂の特徴は第24図のような

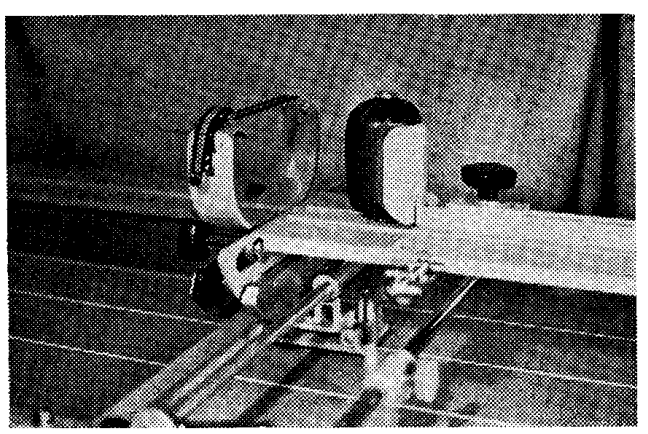

第 20 図

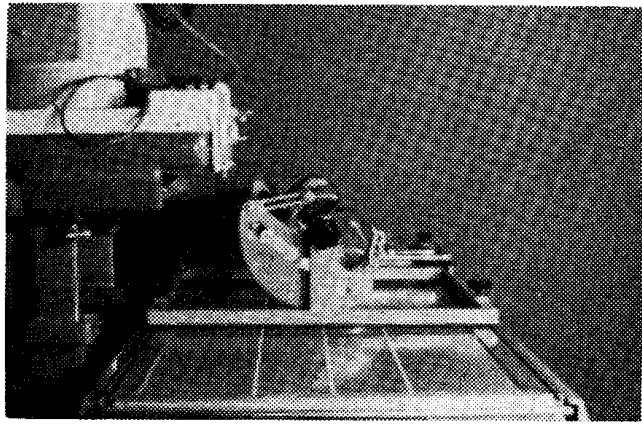

第 21 図

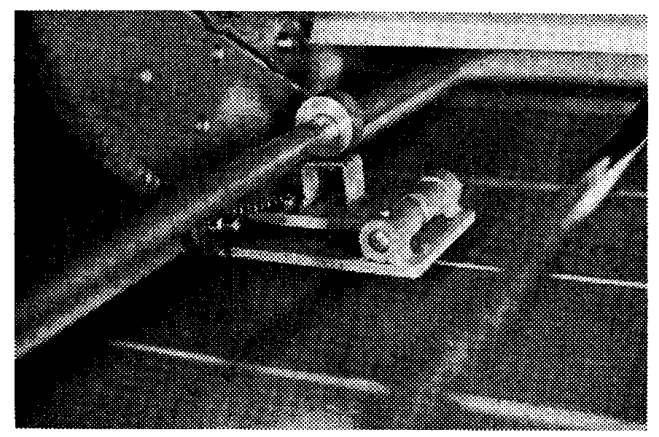

第 22 図

物理的性質:

無色透明ガラス状

属折率 1.5

透過率(光) $94 \%$

衝 撃 值 $20 \mathrm{~kg} /$

$\mathrm{cm}^{2}$ （普通ガラスの 10倍）

比重 $1.1 \sim$

1.2 以内

化学的性質：

$\begin{array}{lrll}\text { 対 } & \text { 薬 } & \text { 品 } & \text { 強 } \\ \text { 対 } & \text { 熱 } & \text { 対可塑 }\end{array}$

性，高熱による解重

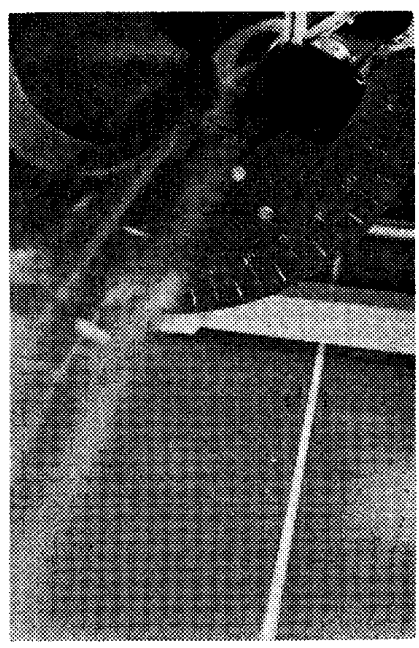
合点

第 23 図

起てし易く $150 \sim 200^{\circ} \mathrm{C}$ で目的 の形に加工可能. 常温で不変

第24図 ポリメタアクリル酸メチル （メタアタリル樹脂）

性質を有するものであり，比重は水とほぼ同じと見做し てより，すなわち樹脂 $6 \mathrm{~mm}$ は水 $6 \mathrm{~mm}$ と同程度のX線 吸収であり $16 \mathrm{~mm}$ シネの画面上にはみとめられず，軽

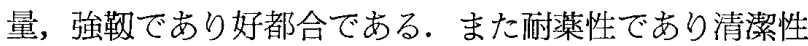
を有している，また長さは $60 \mathrm{~cm}$ であり常に股静脈挿入 部位はアクリル樹脂板より下部に露出され術者の操作に 


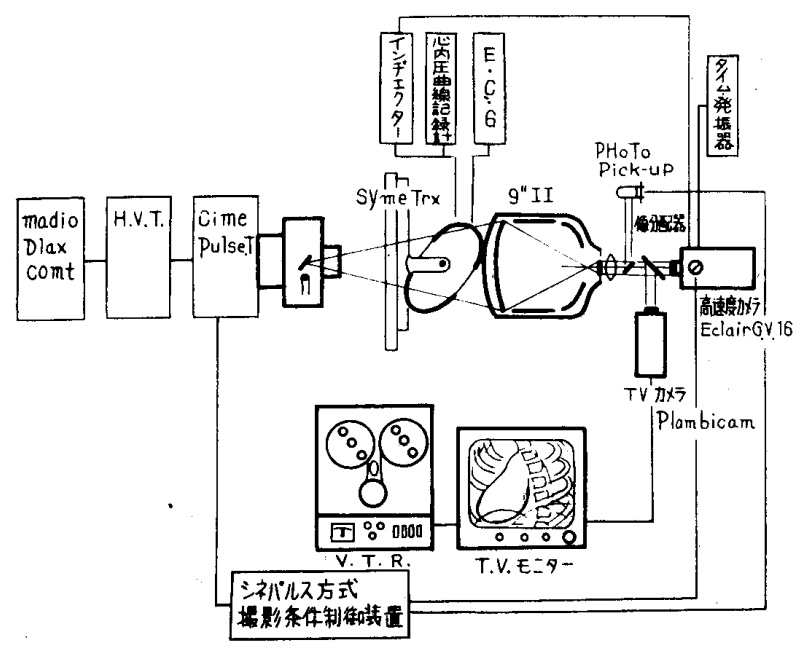

第25図 乳小児心臓血管撮影用各装置の系統図

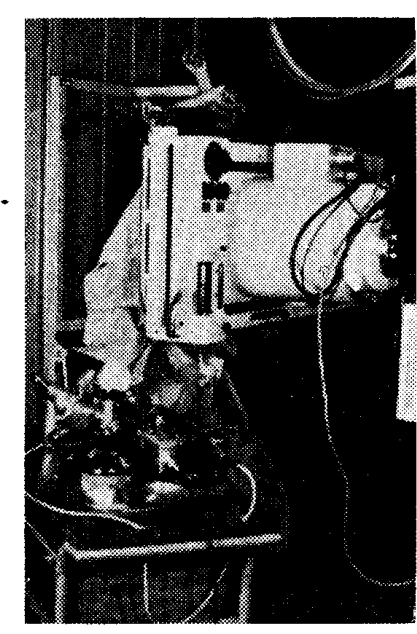

第 26 図

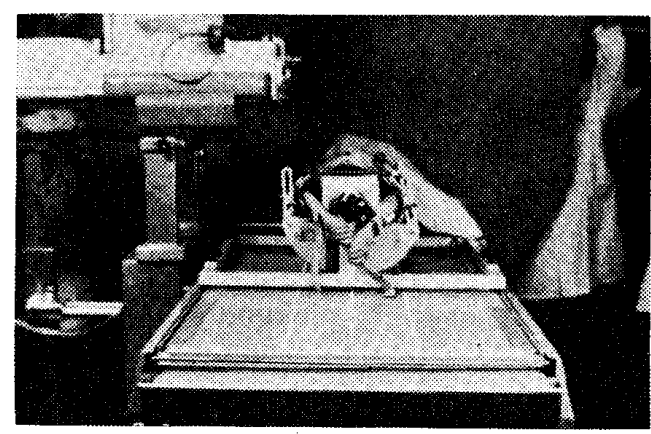

第 28 図

む何んら支障なく三方割栓を介して監視装置に接続がで きる，乙の用具と諸装置との組合わせを第25図で表して あります．その接続状況を第26，27図で表してあり患者 の各体位の状沅は第28，29図で表しております.

以上が実際行なわれている状態であります。

使用器具亡条件

$\bigcirc \mathrm{X}$ 線発生装置 フィリップ製

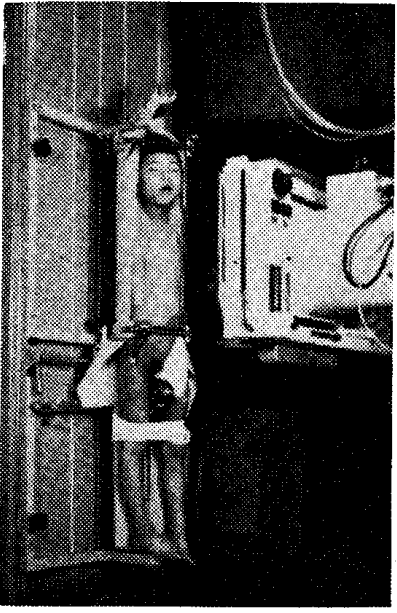

第 29 図

シンメトリックス,メディオ DLX

定格 $125 \mathrm{kVp} 500 \mathrm{~mA}$ 全波整流

$\bigcirc \mathrm{X}$ 線管 Rotalix $-0-90$ 焦点 $0.3,1.2 \mathrm{~mm}$

○ TV フィリップス製（非同期回路）

○撮像管 プランビコン

○ photo pick-up 被写体の厚さとフィルム濃度の 関係を電気露出計にて監視し適 正露出を行なう ( $\mathrm{EE}$ 機構)

○シパルス方式 カメラからシャッターの開闒に 同期した信号を取り出しフィル ム各駒毎にX線をパルスで曝射 させ万方式.

○ カメラ Eclair GV16 工業計測用カメラ f.p.s. $8 \sim 200$

撮影条件（映画）は

$70 \mathrm{kVp} 120 \mathrm{~mA}$ f.p.s. 100

である，以上のような装置により，ファロ一氏四微の患 者を 1 秒間 100 駒をシネパルス方式で $16 \mathrm{~mm}$ 映画を撮影 し，立位臥位による造影剤注入時の心臓の形の相違と造 影剂の進み方をフィルムモーション・アナライザーを用 いて分析したあのが第30図のシェマーである，これにて 立位臥位による両者の相違が非常によく解る.すなわち

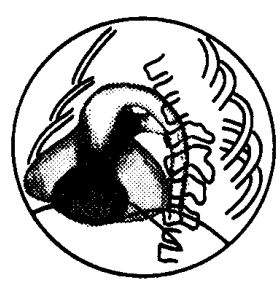

卧 位

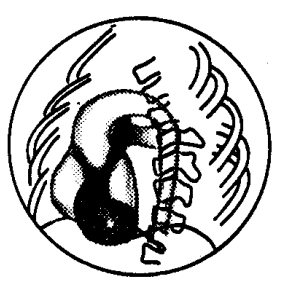

立 位
第30図 $16 \mathrm{~mm}$ フィルムによるX線解析 (モーションアラナイザー16 S ) 
本用具使用に当たっては体位の変化による心臟の形が変 るととと. 体位の再現性, 完全固定, 術者の操作容易等 があげられる。

○モーション.アアナライザー

フィルム定量解析装置で $16 \mathrm{~mm}$ と $35 \mathrm{~mm}$ が分析でき $16 \mathrm{~mm}$ では15倍の拡大ができる.フィルム送転も連続可 変ができ能率よく分析できる.

\section{IV. 簡易脳血管撮影用具}

\section{緒 言}

脳血管への注入方法にはいろいろありますが．頸動脈 の経皮的直接穿刺法による場合には上背部を高く頭部を 後に傾け頸部を伸展させて頸動脈を触指しながら穿刺す る方法が便利で能率的である。 この上うな脳血管造影法 亿適確な固定具の必要が痛感され, 特に夜間緊急患者等 で脳血管撮影を必要とする場合人員が少ないという悪条 件のむとであっも迅速でかつ正確に撮影されなければな りません．そこでわれわれは以上の観点より試作検討し て見た。

試作検討

試作に当たって普通成人の頭部頸部の平均寸法を測定
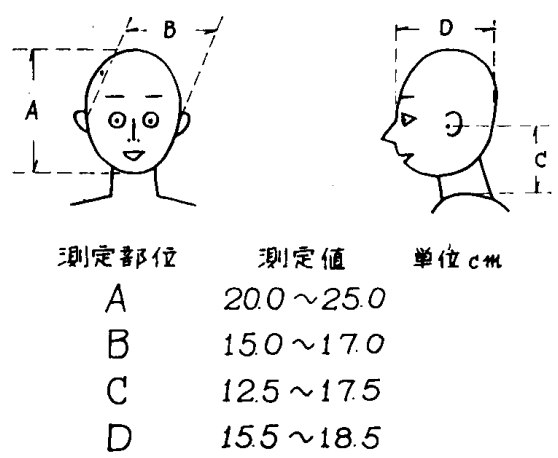

第31図 成人の頭部測定值

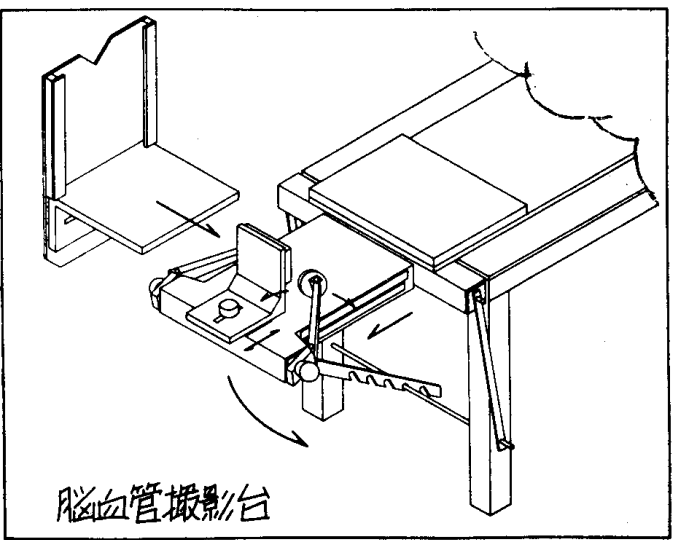

第 32 図

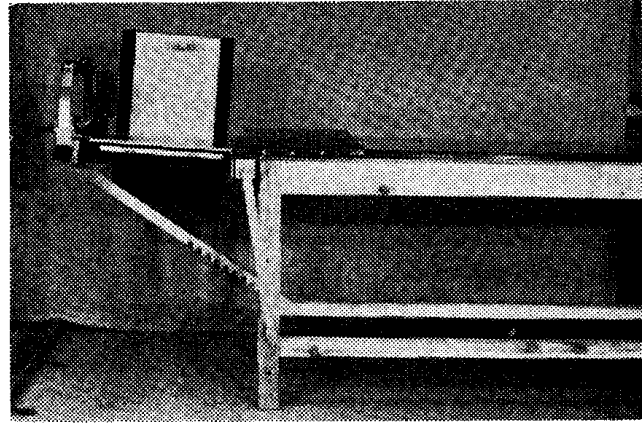

第 33 図

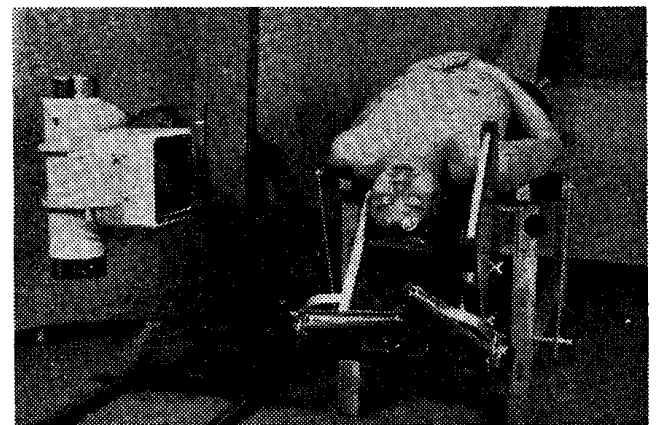

第 34 図

した結果第31図がその值でこれにもとづいて第32，33図 のような頭部固定具を作った．本固定具は頭部固定部之 体部固定部よりなり，その 両者を伸縮自在の金属蝶番 にて連結させた。

したがって頭部固定部は 頸動脈に穿刺し易いように 頭頸部の伸展に応じて 90 度 まで可動させた．第34図が その状態である。

まず正面撮影汇は頭部の 傾を戻して水平位にして行 ない，さらに頭部両側をス プリング内藏の固定アーム にて固定させる。また側面

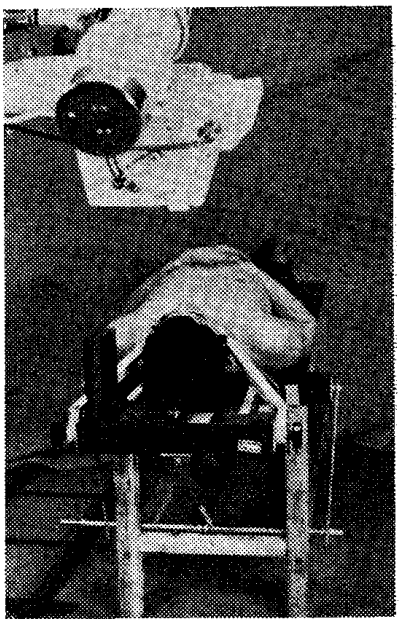

第 35 図 撮影時にはカセッテホルダーと頭頂部を固定具によって

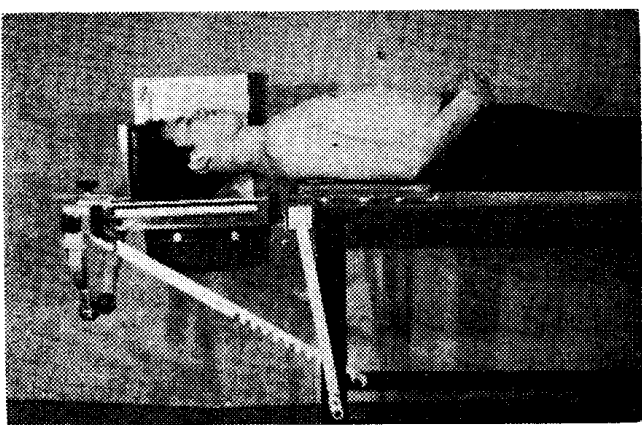

第 36 図 
固定します．との状態が第35，36図である.

したがって必要に応じては同時 2 方向も可能でありま す. 本用具使用によるX線写真が，第37，38図でありま 5.

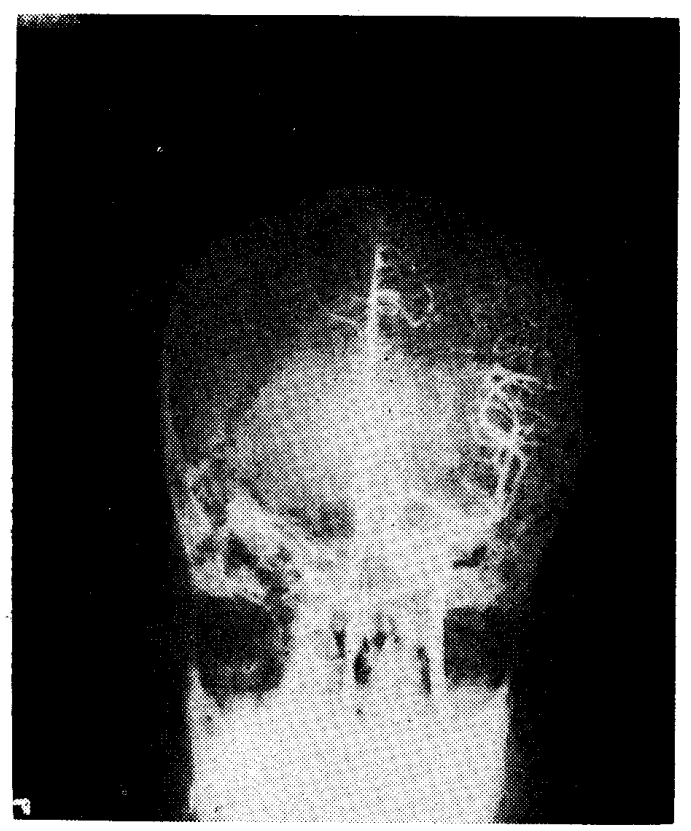

第 37 図

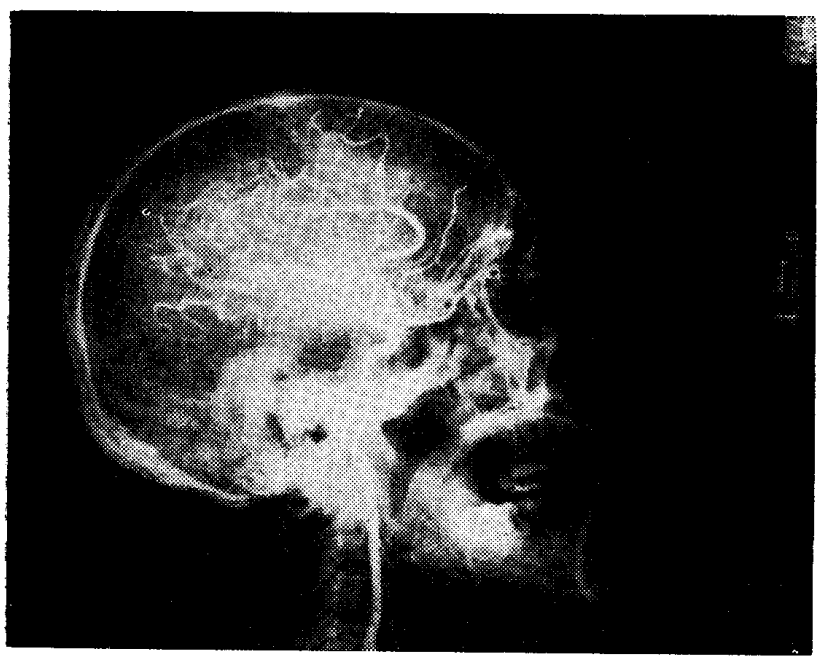

第 38 図

この用具の特徽としては頭部固定部と体部固定部とは 頸部の長短によって伸縮調整が可能なととに一般の撮影 台に简単に取りつけができるとと，したがって術者の操 作容易なととに患者の動摇の防止により，夜間の緊急時 の罒条件のもとです,脳血管撮影に当たって体位の安定， 頸動脈穿刺がより速やかに確実性を増し撮影操作も迅速 かつ正確に実施されるようになった。

\section{V. 脊椎撮影用具}

\section{（1）斜位撮影用具}

\section{諸 言}

脳, 腰椎の 2 方向撮影は比較的安定な状態にありまず ので差程問題にはなりませんが, 斜位撮影においては,い ろいろと問題点があります。斜位 45 度撮影の目的は 2 方 向撮影のみでは診断上困難がある，椎間関節，椎間孔の 状態を良く観察するととにあると思う。その撮影のため には従来いろいろの方法が検討されてきたが，ほとんど 背椎のねじれによって良い写真が得られるとは限らない 現況でありそれ等の原因を検討し試作して見た。

\section{試作検詰}

以上の観点から脊椎全体を斜位にし体表面の背部と前 面のおのおのの個所において角度の測定を行なうことに より脊椎のずれを防止するような用具を試作した。まず 最初に成人の胸腰慰部の側厚と斜位角 (45度) の平均值 を取った結果第39図のとおりである．乙れより第40図の ような用具を試作した。

\begin{tabular}{|c|c|c|c|}
\hline 部位 & 厚 $:(h)$ & 側厘 & 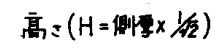 \\
\hline 胸部 & $16 \sim 23$ & $26 \sim 31$ & $18.2 \sim 21.7$ \\
\hline 部 & $17 \sim 27$ & $23 \sim 27$ & $15.1 \sim 18.9$ \\
\hline 部 & $18 \sim 24$ & $2 q \sim 32$ & $20.3 \sim 22.4$ \\
\hline 巾 & $\longrightarrow$ & $35 \sim 45$ & $24.5 \sim 31.5$ \\
\hline
\end{tabular}

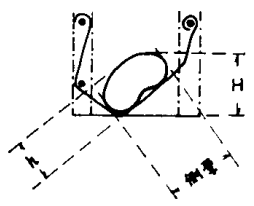

第39図 胸, 腰, 臂部の側厚と斜位角 $\left(45^{\circ}\right)$ との関係

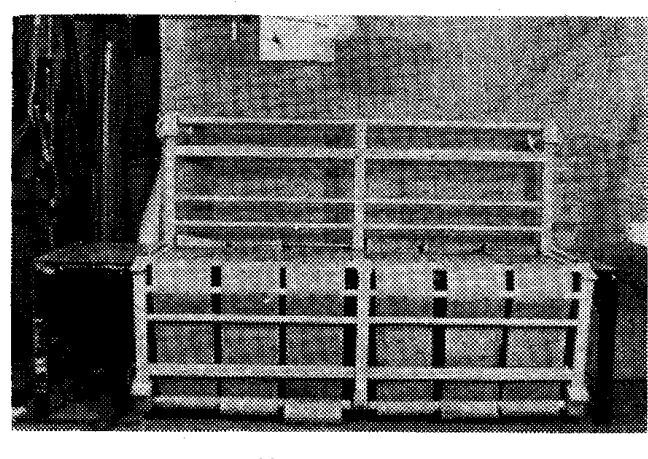

第 40 図

本用具はブッキーテーブルの上に取り付（取はずし可 能）片側は 180 度開くようにしてあり, 患者の出入を容易 にした，患者はハンモック状の6 組の布带上に仰卧位に させ左右の回転ハンドルによってからだ全体が45度に調 節しさらに背部之恥骨結合，胸鎖関節部の各点において 角度を測定し再確䜑を行なう方法である。

本用具の使用に当たっては多少角度調節に時間を要す 
るととと大形であるとと が不便であるが, 本用具 を使用したもの(第42図） と従来の方法によるX線 写真（第43図）を比べる ならば脊椎のねじれ等が すくなく, 椎間関節脊檤 腔の椎間腔の均等性等良 好な結果が得られた。

(2) 立位側面位屈伸 撮影用

緒 言

X線診断は従来の静的

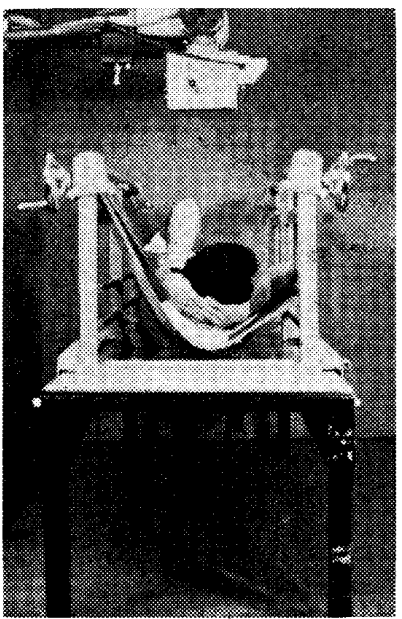

第 41 図 な面のみならず, さらに動的な面へ の診断が要求され るようになってき た. 従来の運動を 有する部位の観察 には映画，キモグ ラフ等がありま すが, 運動時の腰 椎側面像の確認に 最大屈伸運動中に 撮影が要求されて きた.したがって われわれは立位ブ ッキーを利用した 圧迫体等で固定し て撮影しました が，この方法では 椎体の動きに伴っ て骨船等も同時汇 動いた状態の写真 加得られ，椎体自 体の運動のみを得 ることはできない ことが解り以上の 事柄上り新たに試 作検討して見た。 試作検討 試作江当たって は最初纪成人の腰

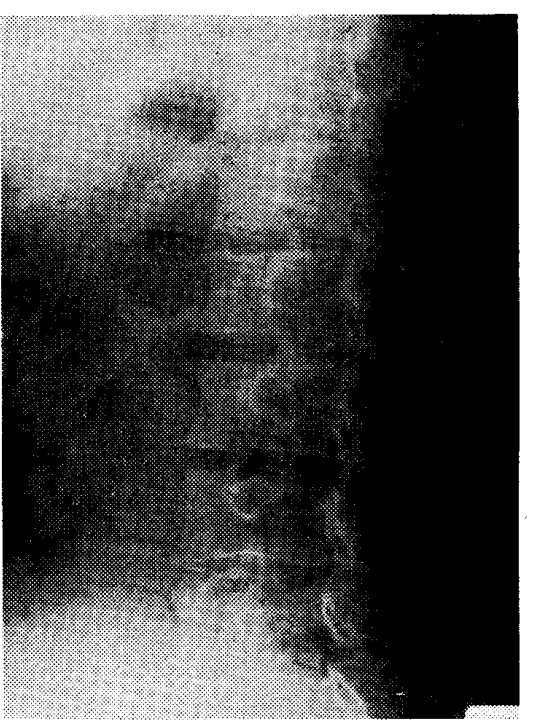
第 42 図

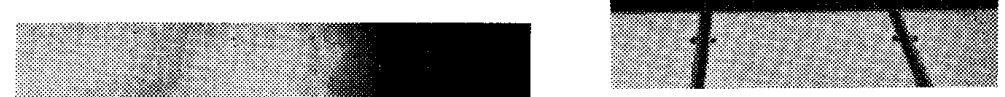

第 47 図

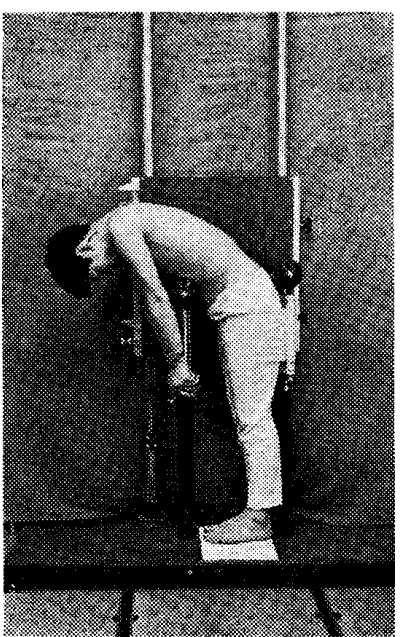

第 49 図

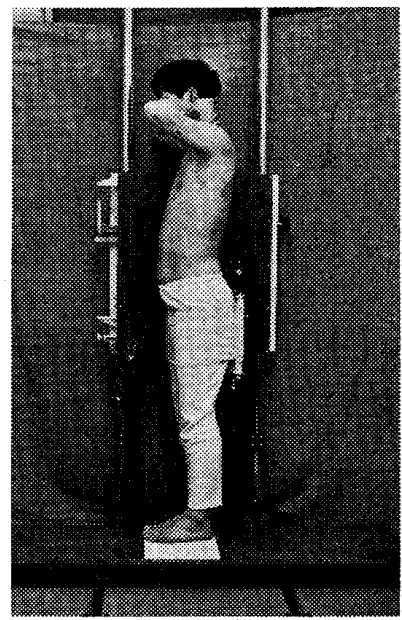

第 48 図

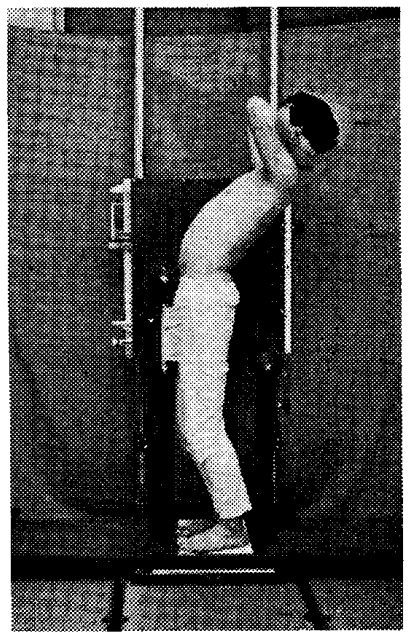

第 50 図 


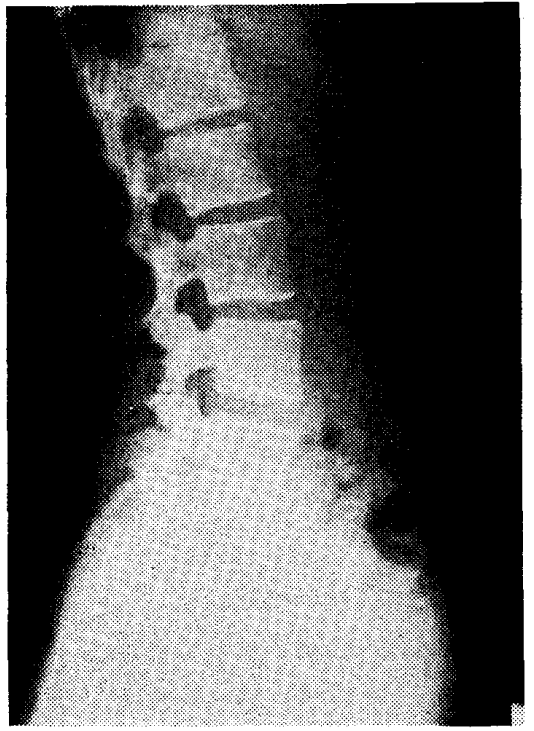

第 51 図

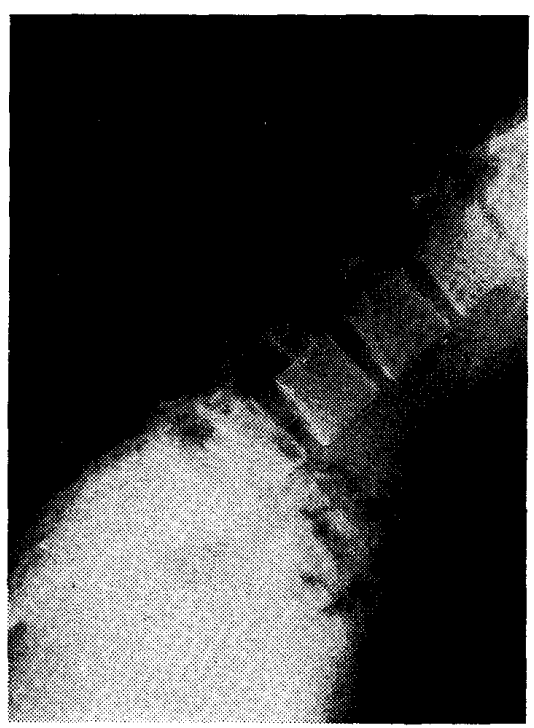

第·52 図

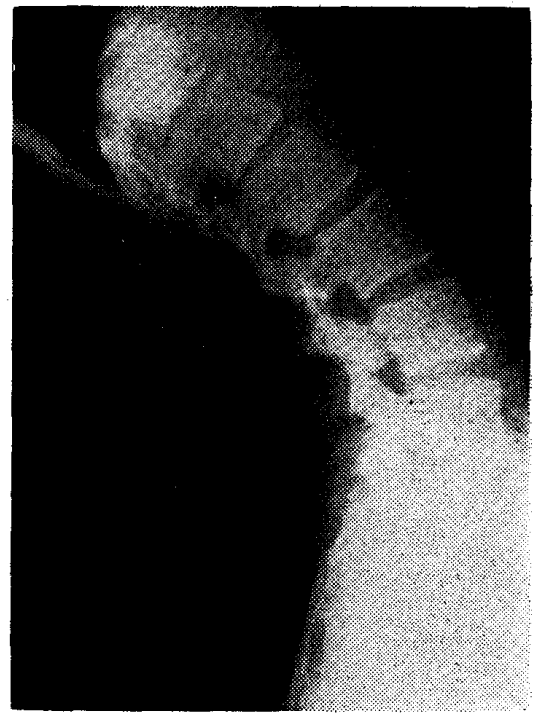

第 53 図
て患者自体の運動を制限しないようにすることが大事で ある。

したがって固定順序を説明するならば 1 本の支柱に圧 迫帯にて骨船下部を固定する第48图である。ついで最大 屈伸を行ないその位置に他の支柱を上下させ動摇を防ぐ ための支へとする第49図のように当てる．またとの逆の 場合む同样に行なう，第51图である。

このようにして得られた写真は第51，52，53図のよう なものであり骨艋を中心に椎体のみの運動の写真が得ら れた。乙れを 3 枚重ねた像のシエーマが第54图である。 本装置は立位ブッキーに改良を加えるととなく利用でき ることと患者の安定と同一軸を中心淈伸できるので比

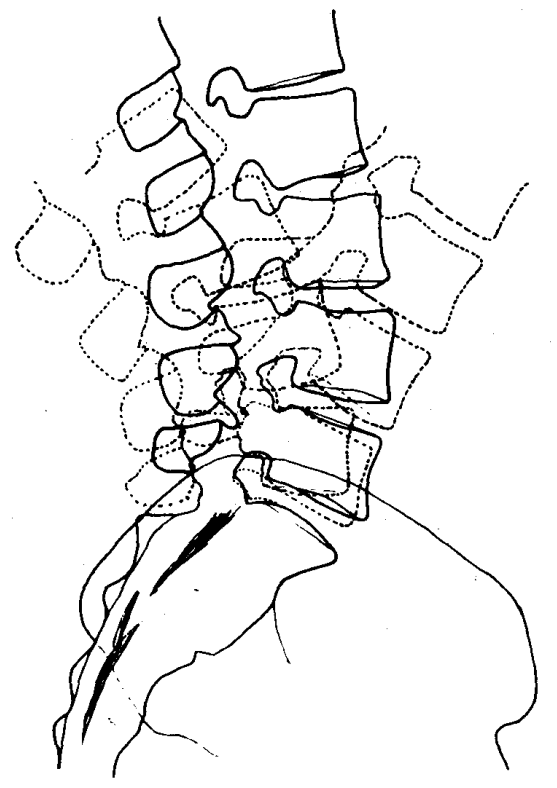

第 54 図
較検討が容易である.

\section{VI. 骨盤および股関節撮影用具}

\section{(1) 緒套}

診断学の向上により, 撮影技術の再現性, 正確さを要 求されるに当たり, 被写部の固定の問題が重要になって きた，同時に，われわれの立場として，放射線防護に慎 重な配慮が必要である.

従来の骨船および股関節の正面像撮影では，下肢の内 または外セン位を安定にすることが允分でなく，また側 面像撮影では有効な固定用具がなく，付添者による固定 を必要とすることすらある，てのような不安定な固定で は正確な再現性は得がたい，乙こで安定かつ確実な固定 法が要求される，われわれはこの要求を満す固定用其を 試作し，との際の撮影法について種々検討した。

なお骨盤および股関節撮影時の患者の被曝量を減ずる 防護用具についてす検討し，性腺被曝防護具を試作した ので報告する。

\section{(2) Positionining $の$ 現況}

1. 従来使用された固定用具

a. 砂袋

b. 固定带（撮影台に付属されて市販されている）。

c. 矩形小マット

d. 三角マット $(90 ， 50 ， 40$ 度の角度を有する）。

等を positioning に応じて使用してきた。（第55図）

2. 従来行なわれている撮影法による現況

正面像撮影は成人の場合，被検者を仰卧位汇し，沌下 肢を伸展して，膝蓋骨が正確に上を向くようにして撮影 する，特別動摇のない被検者に対しては，仰卧位にし固 


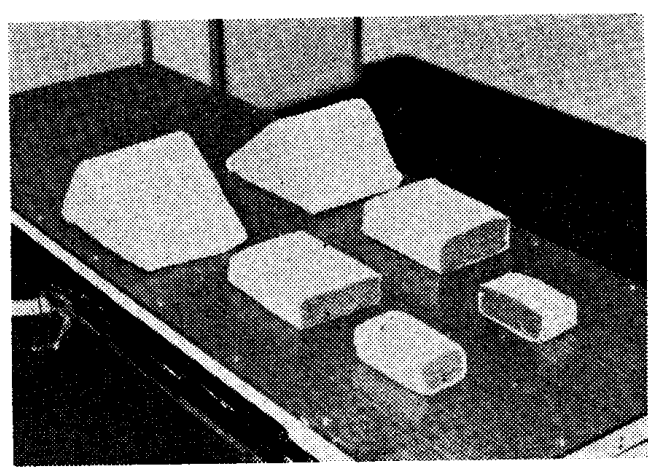

第 55 図

定帯等は使用しないで撮影している. また，病的に動摇 (ふるえ等)のある被検者に対しては，從来撮影台に付属 の固定帯を使用して固定撮影をしている. その他, 左右 股関節の高さが異なる被検者に対しては，矩形のマット を利用し，左右を対称獢正して撮影している.

幼呪の場合は股関節脱臼の検查で，正面像撮影が大部 分であり，股関節計測のために側面像撮影を行なうこと がある. この場合恐怖感等により，動摇がはげしく，下 肢部を付添者がおさえて固定撮影することが多い。

側面像撮影は股関節および大腿頸部撮影が大部分であ り，乙れには種々の撮影法があるが，われわれのところ で主として使用している撮影法について述べる.

a. ラウェンシュタイン氏撮影法においては，股関節 に高度の病変のない場合，または痛みのすくない被検者 に対しては，被検者自身で体位を固定させ撮影する。股 関節の可動性制限の強い場合は，付添者に下肢を固定さ せ撮影する。

b. 大腿骨々頭軸方向撮影法においては，上方または 前方に出した健側下肢とフィルムを付添者に固定させ撮 影する。

ギプスを巻いている場合，乳幼㚾においては両側共巻 くが，乙の場合は大部分が正面像撮影のみであり，小児， 成人においては片側の場合が多く，大腿骨々頭軸方向撮 影法を行なっている。

3. 結果として

従来の撮影法は，正面像撮影において，内外センを防 ぐため膝蓋骨を正確に上を向かせ固定することは実技の 上で，苦学することである，また，側面像撮影において は，健側の下肢を固定することにより，整价ができやす いが，この際付添者の介助を要する．したがって付添者 の被曝は免れない.そこでわれわれは，乙れ等の問題在 解決する固定用具を考案したので報告する.

\section{(3) 試作固定用具}

1. 膝固定器
股関節正面像撮影においては，膝関節を固定する必要 がある．乙の部の固定器として幅 $13 \mathrm{~cm}$, 鿏さ $15 \mathrm{~cm} の$ 半円筒の金属で移動できる方式とし，膝部にあたる固定 器の内側にスポンジをはりつけたものを製作した.（第56 ख)

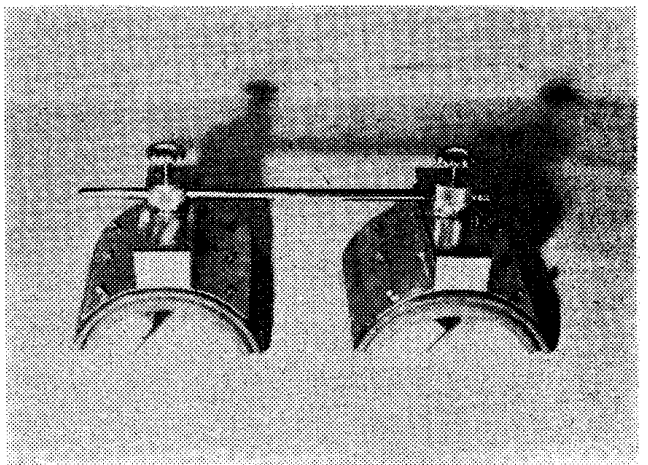

第 56 図

下肢を正確に正面を向かせ固定するのに滕部を固定器 と固定帯の併用により，太さの異なる膝を十分に固定で きるむのを製作し, 正確な股関節正面像を得ることがで きた.（第57図）

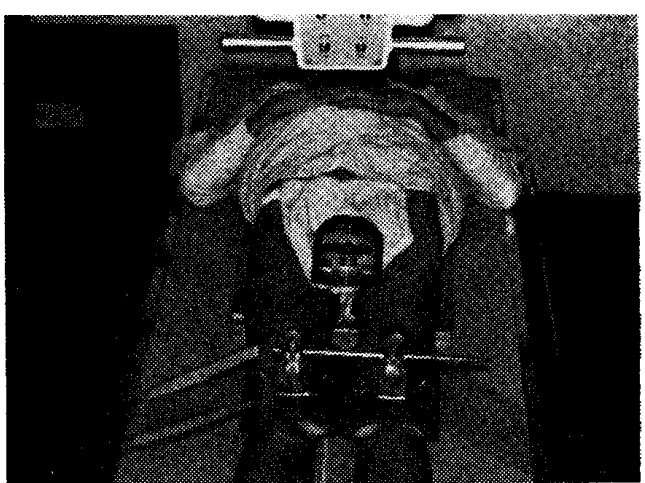

第 57 図

2. 固定帯

従来撮影台に付属されて市販されている固起带を改良 し，幅 $13 \mathrm{~cm}$ 亡 $25 \mathrm{~cm}$ の 2 本の帯を製作し，その帯の幅 $2.5 \mathrm{~cm}$ のマヂックベルトをつけて, 取り扱いを簡易化し, 1 本を下肢にもう 1 本を腰部にして骨盤を固定して, 従 来の帯より簡単で完全に固定できた.

3. 下肢固定器

側面像撮影の場合，患者の固定は正面の場合と同様重 要なととで，患側をむっともよい状態で撮影できるよう に健側の下肢を適当な位置に固定する必要がある．われ われは，ラウエンシュタイン氏法あるいは大腿霄骨頭軸 方向撮影法のいずれにも整位可能な下肢固定器を製作し た。（第58図）

各年代における，平均体格と思われる下肢の長さを約 


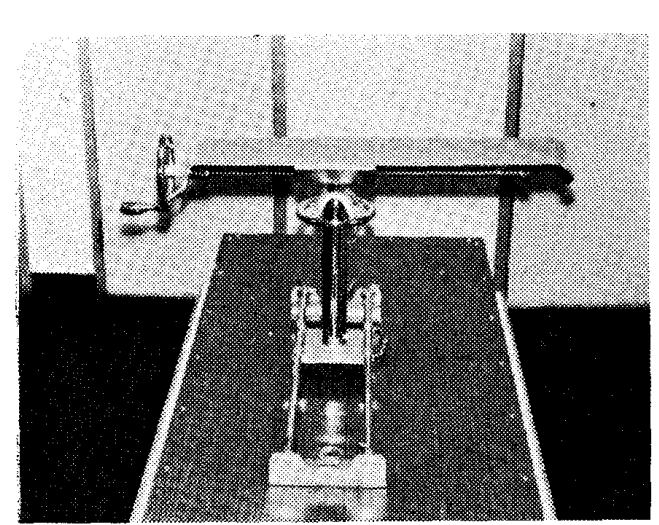

第 58 図

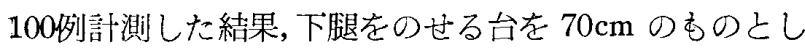
た. その台の水平可動範囲は $50 \mathrm{~cm}$ あり, その上下は撮 影台上より $30 \mathrm{~cm}$ から $60 \mathrm{~cm}$ まで移動できる，また，固 定器は撮影台のよ゙の場合にも取り付けることができるむ のとした。

この固定器を使用するととにより，大腿骨々頭軸方向 撮影法では，完全に障害除影を出さずに撮影できる。 た, ラウェンシュタイン氏撮影法にも応用できる固定器 である.

その他，撮影時において膝関節を屈曲できない被検者 に対しても，下腿をのせる台を上に移動させることによ り使用可能であり，患側の下肢または病的に動摇のある

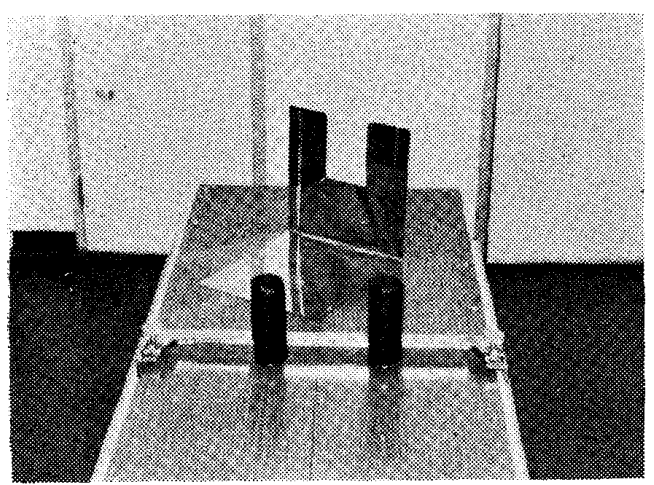

第 59 ，図

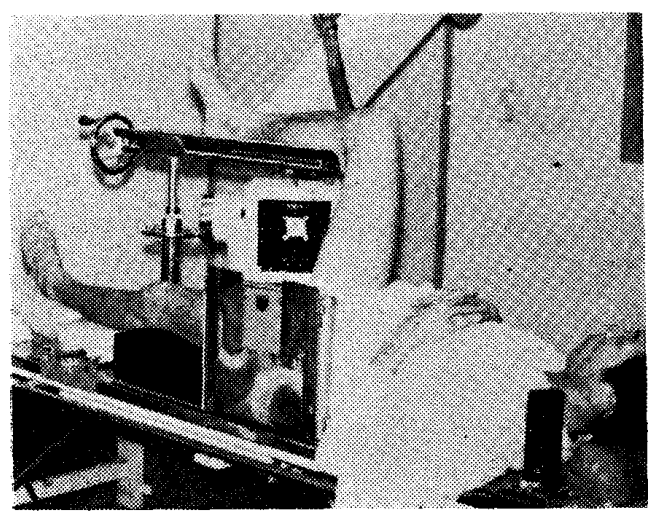

第 60 図
被検者に対しても，固定帯を併用させることにより十分 に固定撮影できた。

この固定器に付属させて瀜あてと簡易取枠支持器を製 作した（第59図）

肩あては大腿骨々頭軸方向撮影法の場合，健側の下肢 を上げて押しつける時に，身体の頭側への移動を防ぐあ のとし，取枠支持器は患側方から摷し込む簡単な方法で 固定器との組合わせにより容易に固定撮影できるもので ある、(第60図)

4. 幼児股関節撮影用固定带

幼児の撮影は動摇するととが多い。この動摇を停止せ しめるために，すべりがなく，身体に密着し，清掃が容 易である塩化ビニール製の带とマデックバンドを用いて 固定帯を製作した。

固定目標を腰部と下肢とし，下肢部は膝にビニール帯 を巻きつけ，撮影台に取り付けたビニールの固定带にて 上より押さえつけて固定する．腰部は撮影台に取り付け てあるビニール帯にて固定する方法であるが，照射野の 部分に吸収のすくないアクリール樹脂板 $(25 \times 30 \mathrm{~cm}$, 厚 さ $5 \mathrm{~mm}$ )を使用して，写真的価值を損わずに動摇を停 此するととができた。

防護装置は特別な支持器を必要としないで，アクリー ル板の上にのせて，目標に合わせて使用することにより， ずれを生じることむなく，固定撮影するととができた。

(第62図)

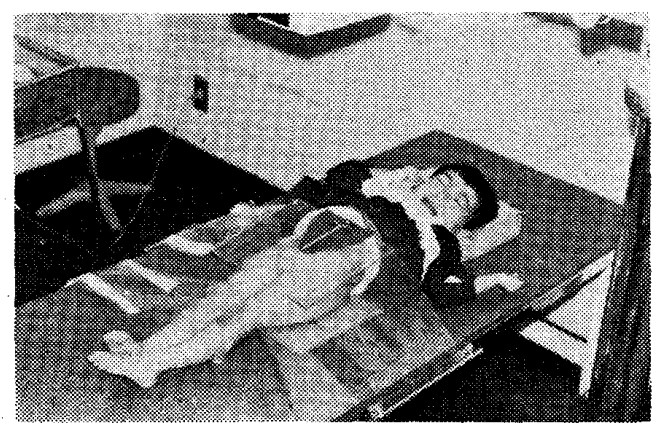

第 61 図

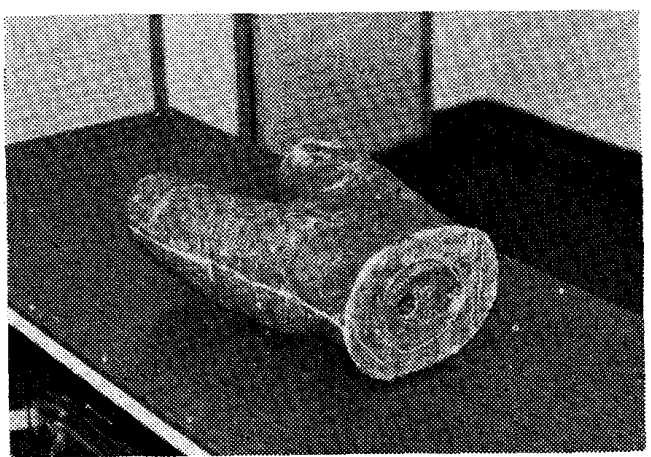

第 62 図 


\section{（4）被曝線量亡減少率}

1. ファントーム

材料にはパラフィンを使用し，成人用は女子の標準体 格に近い大きさとし，幼児用は各年令の女児の平均汇近 い体格を目標として製作した（第62図）

成人用, 周囲 $85 \mathrm{~cm}$, 厚导 $18 \mathrm{~cm}$

幼児用 6 力月 1 歳 3 歳 6 歳

周囲 $39 \mathrm{~cm} \quad 46 \mathrm{~cm} 51 \mathrm{~cm} 59 \mathrm{~cm}$

厚さ $10 \mathrm{~cm} \quad 12 \mathrm{~cm} 13 \mathrm{~cm} 14 \mathrm{~cm}$

男子の場合には，女览および成人女子用ファントーム 范兼用した。

2. 测定器

幼児用科研製ポケット型線量計

成人用東芝製ポケット型線㻎計

コロニアル線量計

被曝線量の測定には女子の場合, ファントームの上方 より穴をあけ，電離槽部分が卵巣部の位置に当たるよう 搟入し, 空間部にパラフィンの棒を埋め, 男子は表面股 間を利用した。

3. 発生装置

幼览用 変圧器式全波整流 $500 \mathrm{~mA}$ 型日立製 成人用 変圧器式全波整流 $500 \mathrm{~mA}$ 型島津製

4. 由心X線

恥骨結合上縁

5. 照射野

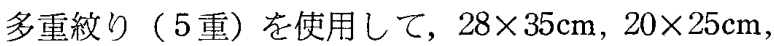
$10 \times 15 \mathrm{~cm}$ の大きさの照射野を用いた。

6. 照射条件

従来撮影に使用している管電圧を目標とした。

幼児用 $40 \sim 50 \mathrm{kVp} 200 \mathrm{~mA} 0.1 \mathrm{sec} 100 \mathrm{~cm}$

成人用 $50 \sim 60 \mathrm{kVp} \quad 100 \mathrm{~mA} \quad 1.0 \mathrm{sec} 100 \mathrm{~cm}$

7. 測定結果

成人女子の場合

$50 \mathrm{kVp}$ において防護なしと防護と紋りの併用の比は，

第 1 表 成人女子の被曝線量減少率

\begin{tabular}{|c|c|c|c|c|c|}
\hline 方法 & 防 護 & （無） & 防 讙 & （有） & $\begin{array}{c}\text { 防護(有) } \\
20 \times 25\end{array}$ \\
\hline $\begin{array}{l}\text { 電 较り } \\
\text { 无 } \\
\mathrm{kVp}\end{array}$ & $\begin{array}{c}28 \times 35 \\
\mathrm{~cm}\end{array}$ & $\begin{array}{c}20 \times 25 \\
\mathrm{~cm}\end{array}$ & $\begin{array}{c}28 \times 35 \\
\mathrm{~cm}\end{array}$ & $\begin{array}{c}20 \times 25 \\
\mathrm{~cm}\end{array}$ & $\begin{array}{c}\text { 防護(無) } \\
28 \times 35\end{array}$ \\
\hline 50 & $\begin{array}{c}\mathrm{mR} \\
104.2\end{array}$ & $\begin{array}{c}\mathrm{mR} \\
89.6\end{array}$ & $\begin{array}{l}\mathrm{mR} \\
13.2\end{array}$ & $\begin{array}{c}\mathrm{mR} \\
9.6\end{array}$ & $1 / 10.9$ \\
\hline 60 & 180.2 & 159.2 & 24.0 & 19.2 & $1 / 9.4$ \\
\hline
\end{tabular}

条件: $100 \mathrm{~mA}, 1.0 \mathrm{sec}, 100 \mathrm{~cm}$. (10回测定平均值)
1/11に減少した。

$60 \mathrm{kVp}$ における減少率は1/9となった。（第 1 表）

成人男子の場合

$50 \mathrm{kVp}$ 亿予ける減少率は $1 / 49$ で， $60 \mathrm{kVp}$ では $1 / 51$ で あり，非常に防護効果がある（第 2 表）

第 2 表 成人男子の被曝線量減少率

\begin{tabular}{|c|c|c|c|c|c|}
\hline $\begin{array}{l}\text { 測定 } \\
\text { 方法 }\end{array}$ & 防 護 & （無） & 防 護 & (有) & $\begin{array}{c}\frac{\beta j}{3} \text { 護 (有) } \\
20 \times 25\end{array}$ \\
\hline $\begin{array}{l}\text { 電 絞 } \\
\mathrm{kVp}\end{array}$ & $\begin{array}{c}28 \times 35 \\
\mathrm{~cm}\end{array}$ & $\begin{array}{c}20 \times 25 \\
\mathrm{~cm}\end{array}$ & $\begin{array}{c}28 \times 35 \\
\mathrm{~cm}\end{array}$ & $\begin{array}{c}20 \times 25 \\
\mathrm{~cm}\end{array}$ & $\begin{array}{c}\text { 防護 (無) } \\
28 \times 35\end{array}$ \\
\hline 50 & $\begin{array}{l}\mathrm{mR} \\
352.0\end{array}$ & $\begin{array}{c}\mathrm{mR} \\
304.0\end{array}$ & $\begin{array}{l}\mathrm{mR} \\
8.8\end{array}$ & $\begin{array}{l}\mathrm{mR} \\
7.2\end{array}$ & $1 / 48.9$ \\
\hline 30 & 592.0 & 552.0 & 13.4 & 11.7 & $1 / 50.6$ \\
\hline
\end{tabular}

条件; $100 \mathrm{~mA}, 1.0 \mathrm{sec}, 100 \mathrm{~cm}$. (10回測定平均值)

幼児女子の場合

$40 \mathrm{kVp}$ における減少率は，6力月で $1 / 13 ， 1$ 歳で $1 / 38$ ， 3 歳で $1 / 29$, そして 6 歳で $1 / 42$ であった. $50 \mathrm{kVp}$.では 6 カ 月で $1 / 11,1$ 歳で $1 / 20,3$ 歳では $1 / 21,6$ 歳では $1 / 21$ であっ た.（第 3 表）

幼児男子の場合

1 歳用ファントームを用いて測定し，減少率は $40 \mathrm{kVp}$ で $1 / 128 ， 50 \mathrm{kVp}$ で $1 / 184$ あった（第 4 表）

以上により防護による效果は大であり，さらに紋りを 併用させるととは，その効果は増大するととができる。

\section{（5）防護装置}

股関節撮影において性殖腺に直接被曝するため，その 被曝量を軽減させるため防護装置を製作し，固定用具己 組合わせて良好なる結果を得た。

1. 体表面上の目標

恥骨結合, 腸骨前上棘, 正中線

2. 計 測

幼児において 6 月から 6 歳まで，成人において10歳 から40歳代まで，各年令の平均に近し体格のX線写真よ おのおのの 20 例計測した幅は, 大腿骨々頭の上端の高さ の骨髄腔径をとり，角度は内径を底辺として，高さを恥 骨結合上縁の点をとった時のものとした。（第64図） 計測平均值

幼児 6 力月 1 歳 3 歳 6 歳

角度 $96^{\circ} \quad 92^{\circ} 96^{\circ} \quad 86^{\circ}$

㽬 $4.9 \mathrm{~cm} 5.2 \mathrm{~cm} \quad 6.1 \mathrm{~cm} \quad 6.8 \mathrm{~cm}$

成人 10 歳代 20 歳代 30 歳代 40 歳代

角度 $109^{\circ} \quad 113^{\circ} \quad 105^{\circ} \quad 120^{\circ}$

幅 $11.7 \mathrm{~cm} 12.7 \mathrm{~cm} \quad 12.8 \mathrm{~cm} \quad 12.5 \mathrm{~cm}$ 


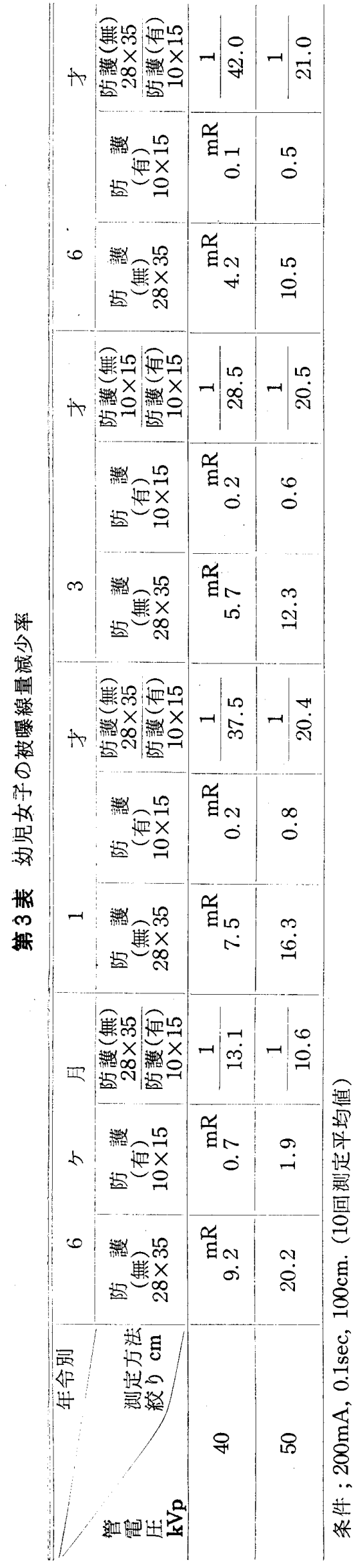

であった。

幼览に拈ける 角度の最低は $80^{\circ}$,最高は $112^{\circ}$ で，幅の最低は $3.6 \mathrm{~cm}$, 最高は $7.6 \mathrm{~cm}$ である. 成人における角 度の最低は $90^{\circ}$, 最高は $134^{\circ}$ で, 幅の最低は 10.6 $\mathrm{cm}$, 最高は 14.5 cmであった。

\section{3. 作 製}

幼帅抒いて 年令汪よる角度 の差はなく，幅 亿年令差がある ととが判明した。

幅汇抄りる差 を利用して，両 側汇均等汇開く 逆梯形の防護装 置を考案した.

開 $<$ 可動範囲 は骨頭上端の高 さで, 最小 $3 \mathrm{~cm}$ で最大 $4.6 \mathrm{~cm}$ ま でのむので, 角 度は最低のもの にした。

成人の場合は 角度招よび幅に 年令差はない。 防護装置を年令 に合わせて使用 できないが，2 回目の撮影より 使用する。

1 回目のX線 写真より骨盤腔 の幅を測定して， 防護装置の拡大 率を考慮に入れ
第 4 表 幼児男子の被曝線量減少率

\begin{tabular}{|c|c|c|c|c|}
\hline \multirow[b]{2}{*}{$\begin{array}{l}\text { 電 絞 } \\
\text { 王 } \\
\mathrm{kVp}\end{array}$} & \multicolumn{2}{|l|}{ 防 護 } & \multirow{2}{*}{$\frac{\text { 防護（有） }}{10 \times 15 \mathrm{~cm}}$} & \multirow{2}{*}{$\begin{array}{c}\begin{array}{c}\text { 防護(有) } \\
10 \times 15\end{array} \\
\begin{array}{c}\text { 防護 (無) } 2 \\
28 \times 35\end{array}\end{array}$} \\
\hline & $\begin{array}{c}28 \times 35 \\
\mathrm{~cm}\end{array}$ & $\begin{array}{c}10 \times 15 \\
\mathrm{~cm}\end{array}$ & & \\
\hline \multirow{2}{*}{40} & \multirow{2}{*}{$\frac{\mathrm{mR}}{12.8}$} & \multirow{2}{*}{$\begin{array}{l}\mathrm{mR} \\
12.1\end{array}$} & \multirow{2}{*}{$0.1^{\mathrm{mR}}$} & 1 \\
\hline & & & & 128 \\
\hline \multirow{2}{*}{50} & \multirow{2}{*}{27.6} & \multirow{2}{*}{22.0} & \multirow{2}{*}{0.15} & 1 \\
\hline & & & & 184 \\
\hline
\end{tabular}

条件；100mA, $0.1 \mathrm{sec}, 100 \mathrm{~cm}$. (10回測定平均值)

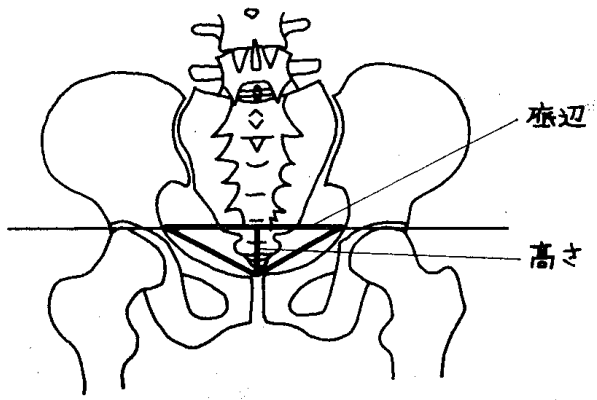

第 63 図

て使用し，幼児の場合之同様雨側に均等に開く形のもの とし，骨盤腔を完全に覆うことができるよう円弧をむた した。 また，成人の場合 1 回目のX線写真を防護装置な

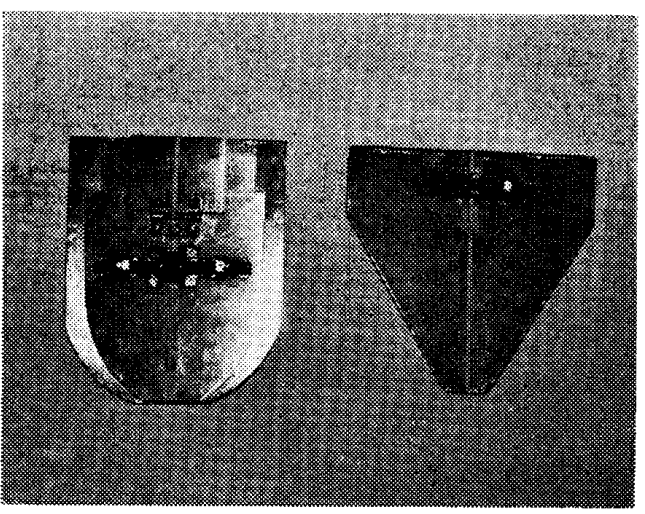

第 64 図

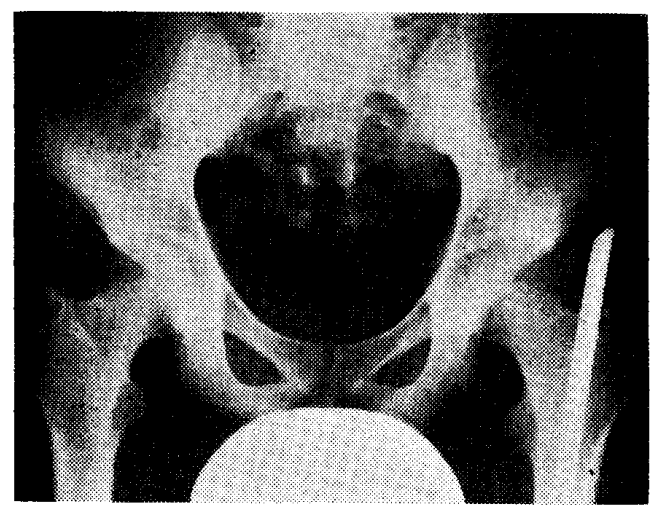

第 65 図 


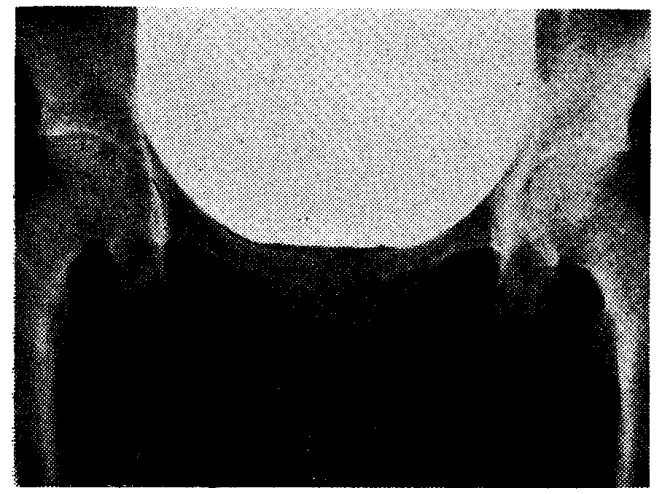

第 66 図

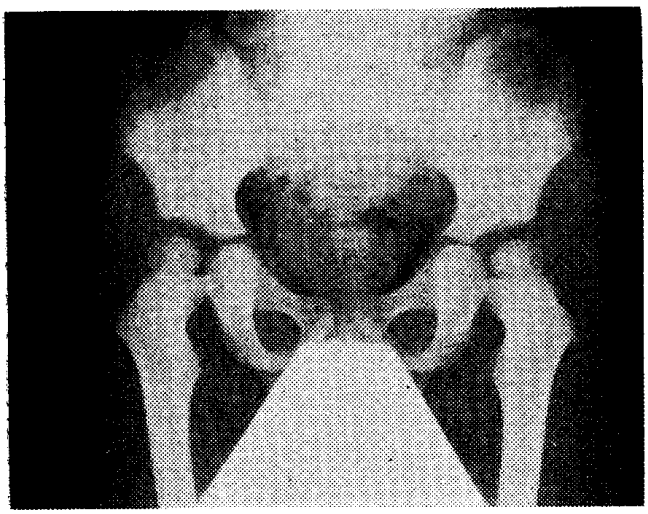

第 67 図

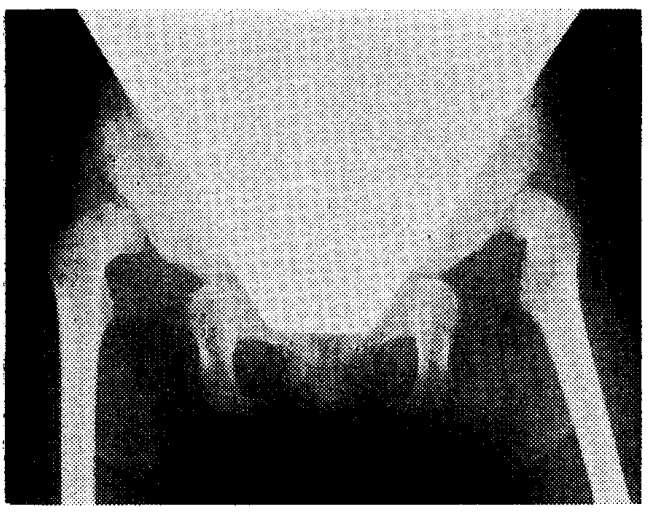

第 68 図

しで撮影するととにより，骨盤全体としてのバランスの 状態や変形を検查し得るので，乙の点からも合理的であ 万.

门弧は平均体格と思われる各年代20例を計測して，そ の平均の円を使用し，円形のまま両側に開く装置で，骨 頭上端の高さで最小 $8.9 \mathrm{~cm}$, 最大 $11.9 \mathrm{~cm}$ まで可動範囲 を持つ装置である.（第65図）

使用結果は成人男子は(第66図)で，成人女子は（第67 図）で奻児女子は（第68図）で，良好であった。

\section{（6）股関節移動近接撮影法}

\section{1. 目 的}

股関節側面撮影には，種々の方法があるが，正確な側 面像を得るのに，その positioning に苦学を要するあの である。

現在われわれが，側面像撮影に用いているラウエンシ ュタイン氏法においては，大腿の側面像であって，股関 節は斜位に近いものであり，また，大腿骨々頭軸方向撮 影法においては骨頭部の歪の大きい像であり，完全な側 臥位撮影では，股関節側面像として診断に役立たない。 そこでわれわれは，固定および整位が容易で，かつ正確 な側面像撮影を行なうために種々の検討をした結果，X 線管移動近接撮影法を行なった。

\section{2. 実験方法 \\ (1) Test chart}

太さ $1 \mathrm{~mm}$ の鉄線りン グをフィルム面より 2.5 , $10,14,22,26 \mathrm{~cm}$ の高さ にはめ込んだ直径 $5 \mathrm{~cm}$ ， 高さ $26 \mathrm{~cm}$ の円筒形 Test chart を製作した.（第69 図)

(2) 実験結果

X線管を $20 \mathrm{~cm}$ 垂直移
第 69 図
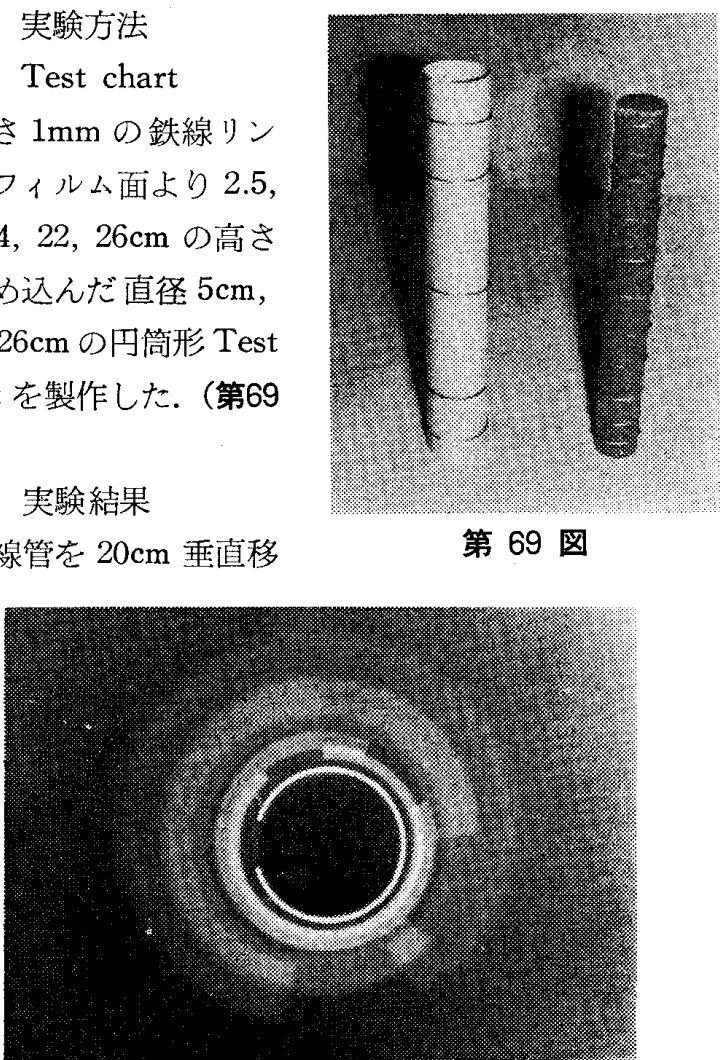

第 70 図

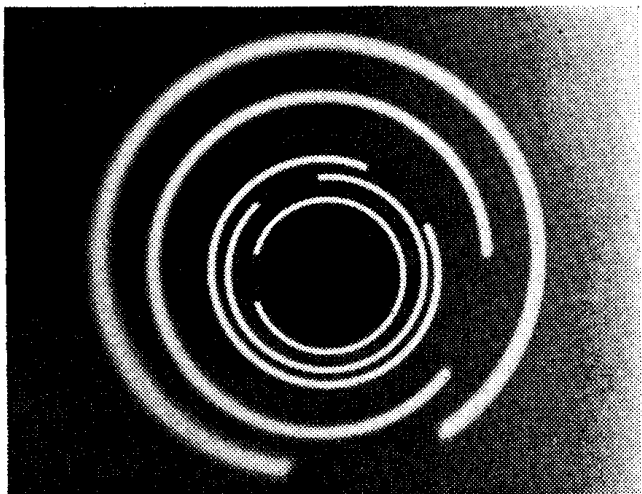

第 71 図 
動させて撮影したものと（第70図）X線管を近接固定し て撮影したもの（第71図）とを比較検討した結果，フィ ルム面より $10 \mathrm{~cm}$ 以上は完全に最かされているととが判 明した。

股関節は皮膚面より 5〜 $7 \mathrm{~cm}$ の深さにあるので, 以上 の実験から股関節側面撮影にもX線管移動近接撮影法が 応用できる。

\section{(3) 撮影実技}

被検者を側臥位にし, 撮影部位をカセッテに密着させ 中心X線は両股関節を通すようにし, 健側股関節にX線 管を密着させて, 重直に移動させると同時にX線を曝射 した.

装置は東芝製天井走行型を使用し，管球の移動距離は $20 \mathrm{~cm}$ である.との装置の上下移動部に $20 \mathrm{~cm}$ の間隔で 2 個のリミットスイッチを取り付讨，管球上下のストッ パーを切ると移動を始め, 2 個のリミットスイッチ間で X線が，曝射されるようにし，乙の，場合の曝射時間は 1.5〜2.0 秒であるように改造した。（第72図）

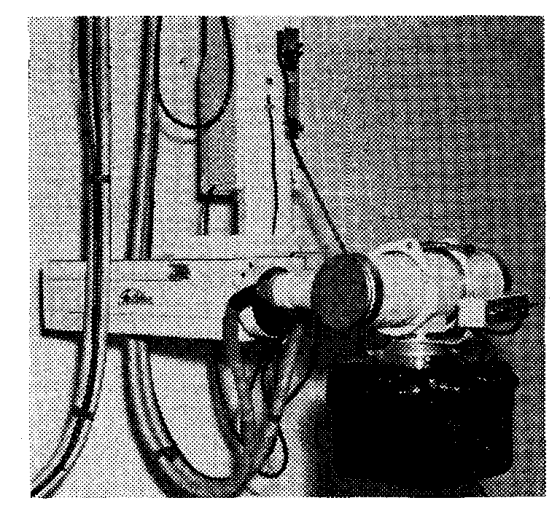

第 72 図

側面像撮影は比較的高電圧を必要とするため, 散乱線 除去の手段を構じなければならない。われわれは種々試 みたが，5:1 のリスホルム・ブレンデは散乱線を充分に 除去し得なかった。 また，8:1 および 12:1 のシングル・ グリッドでむ満足すべきものが得られなかったが，8:1 のクロス・グリッドの使用によって，始めて良好な側面 像を得ることができた。（第73図，第74図）

撮影条件は被写体の厚さ $30 \mathrm{~cm}$ では

$95 \mathrm{kVp}, 100 \mathrm{~mA}, 1.5 \mathrm{sec}$

ただし，FS 増感紙ならびに 8:1のクロス・グリッド を使用する。

(4) 撮影結果

従来の撮影法で得られる股関節側面像は完全な側面像 でないもの，あるいは歪の大きいあのであったが，との 方法によって，重なっていた股関節および大腿を除去で

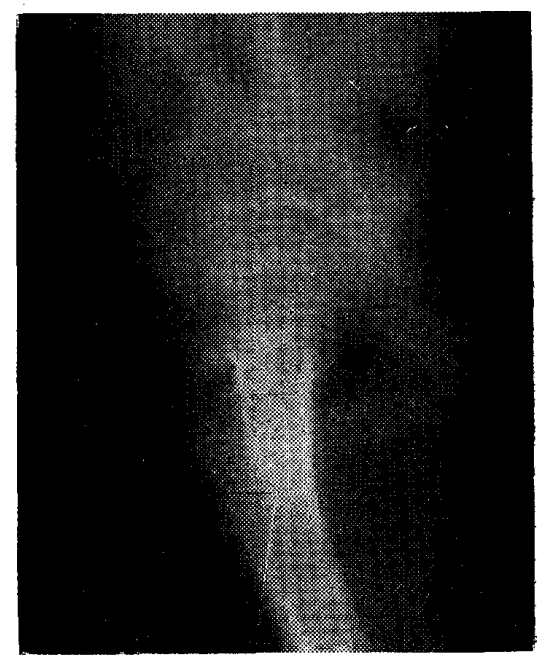

第 73 図

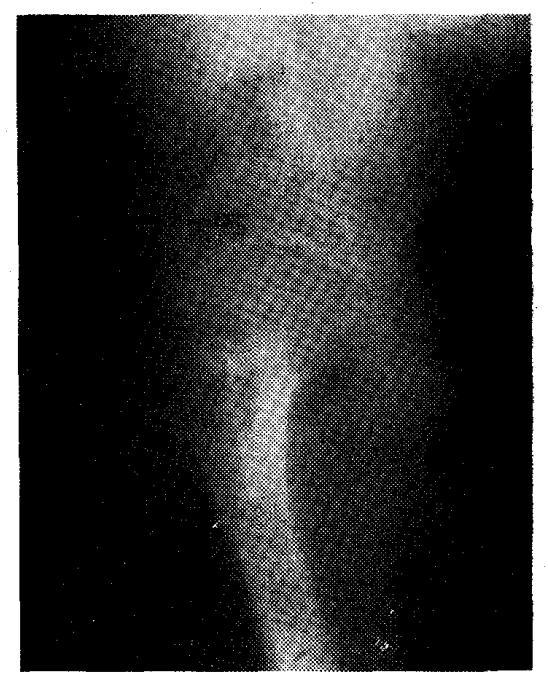

第 74 図

き目的とする股関節の正確な側面像が得られた。この像 は西脱関節症などのどとく，大腿骨々頭の変形の強い症 例には殊に洒值のおる撮影法である。

また，乙の撮影法は完全な側卧位で行なえるから，特 別な, 固定用具を必要とせず, 容易にしかも簢単に整位, 固定できる.

\section{VII. 結論。謝辞}

以上われわれの考案した補助用具は，その根本的な条 件を全て完備されたとは決して考えてはいませんが，従 来の Positioning より正確に再現性のある Positioning. が可能になった．今後はよりよい positiong が如何なる われわれにす可能になるよう，検討を重ねて行く所存で あります。本シンポジゥムの機会を与えて下さった，会 長に感謝の意を表するとともに本研究に当たり終始御指 導を頂いた東北大学星野文彦先生始め諸先生，北游道大 学中央放射線部々長若林教授，整形外科岩田千男講師は 
じめ皮験に御協力を頂いた放射線部の諸氏に心から感謝 の意を表します。

\section{参 考 文 献}

1) K. C. Clark : Positioning in Radio Graphy

2) Darling, Donald B. : Radiography of infants and children.

3) Merrill Vinita : Atlas of Roentgenographic positions.

4) 中村 実: 富士XレイNo. 48〜

5) 三羽忠広：合成樹脂の化学

6) 中村 実:日放技21巻 1 号 29

7）柴山孝行：日放技 17 巻 133

8）高橋康久：日放技 21 巻 10

9) Henri Desgrez 他: X線解剖学

10）高橋信次：X線撮影と検查の手びき

11）横井勝朗，福田央：人体 $X$ 線撮影法

12）松田忠義他：X線管移動近接撮影法日医放, 第22巻 第 12 号

13）立入弘他：股関節撮影時の $\mathrm{X}$ 線防禦について 日医 放 第19巻 第 10 号

14）中村実：被潁量减少に関するもの 日放技 第17巻 第 $3 ， 4$ 号 第18巻 第 1 号

15）伊場昭三他：生殖腺被曝線量の测定 日放医 第19 巻第 4 号

16）山口福司：乳幼児胸部撮影台および股関節撮影台の 試作について 日放技 第18巻 第 4 号

\section{質疑，追加，討論}

(1) 岡崎君に

側面脊椎撮影用具で位置付けが容易でしょうか. 耐椎 間腔の不揃い（従来）があると言われるが解剖学的にど うしてであろうか。

(2) 松本君に

発泡スチロールの消瑇は.

(3) カセッテの横開きがよいか，たて開きがよいか。

(福井 山本)

\section{(1) 岡橋君に}

撮影用具に利用される資材で重要なととはX線の吸収, 強度と言う点が一番重要な因子であるが, 将来どんな物 質がもっとも利用される傾向にあるか.

(2) カセッテの材質でベークライトと $\mathrm{Al}$ 板のいずれ があっとも広く利用されているか. それぞれどんな特徵 があるか。

(3) 岡崎君に
撮影用具として一般病院で備えなければならない最底 の数とどんな種類が必要.

(4) 松本君に

発泡スチロールの良否について. (東京 山本)

(1) 岡崎君に

ハンモックを利用して幼览の撮影をする場合の下肢の 固定はどうしているか. スライドではなにもされていな いようだが.

(2) 股関節撮影時の性腺防護に，アクリル樹脂（厭さ $5 \mathrm{~mm}$ )を使用されているが，それだけか鉛を使用しては。

(3) 岡橋君に

幼児股関節の固定について股関節だけでなく膝関節の 固定を允分にされると安定感が増し撮影が楽と思うが.

(4) 追加

胸部撮影時の固定について, 近時胸部撮影に, 高圧撮影 が多く使用されるようになり，散乱線除去のために高在 撮影用ブッキーが使用される関係上, どうしてもス方プ ラの除去が困難であると言う久点がある.そこでその除 去法としてブッキ一前面に中央の厚さ 7 $10 \mathrm{~cm}$ 幅 $25 \mathrm{~cm}$ のカマボコ型の発泡スチロールを取りつける。これによ りスカプラを外側に開くことができるようになりスカプ ラを除去できる，その上金属板に直接八ダをつけるあの 不快さむなく得である.ただしフィルムと被写体間が開 くことになるが，現在のX線管焦点が多く $2 \times 2 \mathrm{~mm}^{2}$ あ るいはそれ以下であるのでボケの心配は全くない。

次に乳幼児の胸部撮影用固定具について，耐手を軀幹 に添えて僌布等の大きい布で局から軀翰，下肢をスマキ 式に巻く方法で正反射も手伝って幼児仕例え泣いてもど たばたできず，介助者はなくてもよい．ただしこの場合 立位でつり下げるのがよいが撮影は卧位でも立位との差 はない。（体位による肺面積比の差なし）

(増野)

なおカセッテの表面に発泡スチロールの薄いすのを教 き冷感を除くことも必要である。また乳幼児の滕をのば したままで痛くないように当てものをして撮影台に強く 固定すれば身体の動きを防げる．要するに膝の力を抜く ことが乳幼児の体位固定の根本である. 次に手指骨の側 面は手を握った形で小指から順に外側にひろげ 4 本の指 が重ならないようにした状態に合致するように握る台を 発泡スチロールで大，小幾つかを作っておくと固定が容 易である. この場合，拇指は前後像となる．なおとの方 法では示指はフィルムから可なり離机るが寻基上の影響 はほとんど無視できる。

(福岡 村橋)

(1) 腎孟尿管压迫法㧍よび器具.

(2) 発泡スチロールを使用する場合, 穴ぐりで体型を 
つくるに必要なサイズを如何程の間隔で行ないしや.

(3) 発泡スチロール使用のためにカセッテ間距離が当 然生ずるが，乙れが彰断上におよ括す影響如何.

(石川山本)

(1) 女子股関節撮影時の卵宩しゃ蔽について, 性腺防 護の見地からはなるべく広い方がよいが読影者からみる となるべく障害陰影はすくない方がよい. 最小にして有 効なしゃ蔽のためには卵棵の位置の個人差, 小児と大人 の違い等について知っておら标ばならぬがそれに関する 統計を調べられたととがあるか，あるとすればどのよう になっているか御教示願したい。

(福岡 熊谷)
(1) 発泡スチロールには四種類以上の密度差を有する むのがあるが，どの品種の物で形をとられたか. 各密度 によってX線の吸収を有するものもあることを私達は実 験しているがどのような結果を得られたか.

(愛知 加藤芳郎)

(1) positioning には動くものを固定するととと基本 線を正しく整位するとととあり，今日の要求は正しい整 位の方が重要ではないか，発泡スチロールだけでは基本 線をチェックできないのではないか，殊に頭部において は?.

(関西 林)

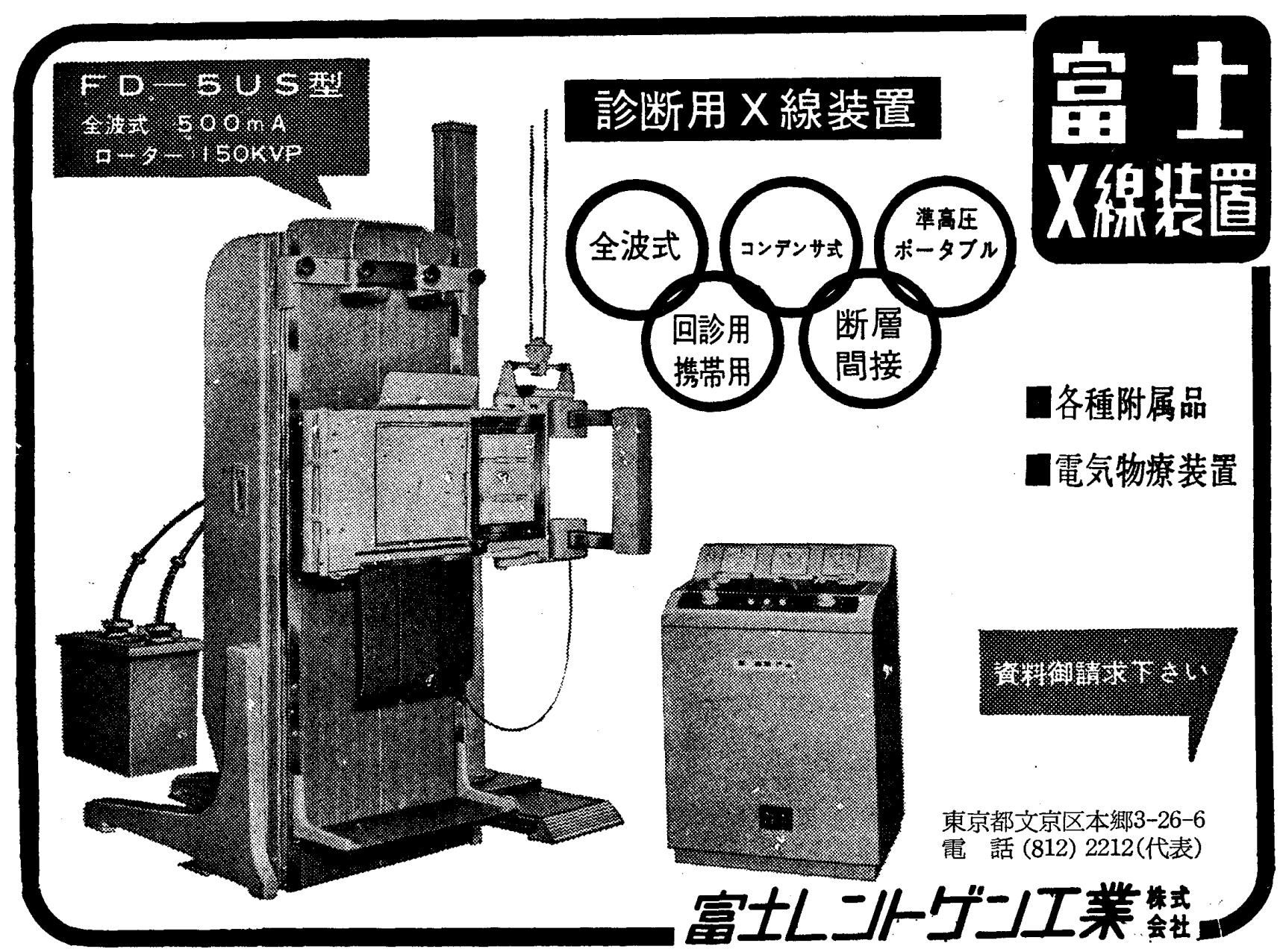

